\title{
Benthic nutrient fluxes in euphotic sediments along shallow sub-tropical estuaries, northern New South Wales, Australia
}

\author{
Angus J. P. Ferguson*, Bradley D. Eyre, Jennita M. Gay \\ Centre for Coastal Management, Southern Cross University, PO Box 157, East Lismore, New South Wales 2480, Australia
}

\begin{abstract}
Diurnal benthic fluxes of dissolved inorganic and organic nitrogen (DIN and DON) and dinitrogen gas $\left(\mathrm{N}_{2}\right)$ were measured in euphotic sediments of 3 shallow sub-tropical Australian estuaries during 4 seasons. The estuaries included 2 impacted by sewage effluent (Brunswick and Simpsons estuaries) and 1 relatively pristine system (Sandon estuary). Sediments acted predominantly as net sinks of DIN throughout the year, except in the nutrient-enriched upper reaches of the Brunswick estuary, where large effluxes of $\mathrm{NH}_{4}{ }^{+}$occurred during the summer wet season. Distinct light/dark variations in $\mathrm{NH}_{4}{ }^{+}$fluxes with reduced effluxes or reversal to uptakes occurred during the light in productive sediments. $\mathrm{NO}_{3}{ }^{-}$was predominantly taken up by sediments at rates proportional to ambient concentrations in the water column. DON commonly comprised a major fraction of fluxes and was controlled primarily by heterotrophic processes in the upper to middle estuaries and autotrophic processes in the lower estuaries. Large deficits in the amount of remineralised DIN (assuming the breakdown of 'Redfield' algae) indicated that a significant amount of nitrogen is either denitrified or immobilised in biomass in the sediments. Benthic fluxes of $\mathrm{N}_{2}$ suggest that denitrification accounts for a relatively small fraction of the missing nitrogen and immobilisation in biomass (and flow up the food chain) is a potentially major pathway of nitrogen removal in these estuaries. Significant rates of benthic productivity also stimulated secondary heterotrophic production, promoting competition for nutrient resources in the sediments. The highest rates of DIN uptake coincided with maximum metabolic rates in sediments where the diurnal $\mathrm{p} / \mathrm{r}$ (gross productivity/respiration) was between 0.5 and 1 , suggesting a peak in competition at this metabolic state. Denitrification rates were lowest at $\mathrm{p} / \mathrm{r} 0.5$ to 1 and strongly related to uptake of DIN from the water column, suggesting that competition may cause $\mathrm{NO}_{3}{ }^{-}$limitation in these euphotic sediments. Dissimilatory $\mathrm{NO}_{3}{ }^{-}$reduction to ammonium may become relatively more important as water column oxygen saturation drops below $40 \%$, a condition that occurs regularly in the upper Brunswick estuary. $\mathrm{NH}_{4}{ }^{+}$was only effluxed in net heterotrophic sediments $(\mathrm{p} / \mathrm{r}<1)$, while fluxes tended towards zero in net autotrophic sediments $(\mathrm{p} / \mathrm{r}>1)$. A conceptual model for benthic nutrient cycling in shallow sub-tropical estuaries is proposed whereby benthic productivity favours to the immobilisation of nitrogen in biomass at the expense of denitrification and recycling back to the water column.
\end{abstract}

KEY WORDS: Benthic nutrient fluxes $\cdot$ Sub-tropical estuaries $\cdot$ Gross productivity/respiration $\cdot \mathrm{p} / \mathrm{r}$ · Immobilisation • Benthic microalgae

Resale or republication not permitted without written consent of the publisher

\section{INTRODUCTION}

Benthic nutrient fluxes have long been recognised as being an important component of estuarine ecosystems due to their ability to significantly influence water quality (Nixon 1981, Blackburn \& Henriksen 1983,
Boynton \& Kemp 1985, Kemp et al. 1990, Rizzo \& Christian 1996). In particular, benthic ammonification and denitrification are known to be significant sources and sinks, respectively, of bio-available nitrogen to the pelagic zone (Rudek et al. 1991, Overnell et al. 1995, Reay et al. 1995). Sediments are major sites for the 
microbial mineralisation of organic matter (OM) delivered from catchment runoff and produced by pelagic phytoplankton, commonly resulting in the recycling of nutrients to the water column thereby fuelling further pelagic productivity (Hammond et al. 1985, Blackburn 1988, Cowan et al. 1996). Benthic fluxes have therefore been the subject of considerable research effort due to their potentially important role in the process of eutrophication (Jørgensen 1996).

Early models of benthic nutrient cycling were based on net heterotrophic sediments and showed fluxes as primarily net nutrient sources to the water column. Flux measurements were commonly made in the dark since there was significant attenuation of light at the sediment surface, and benthic metabolism was driven by the heterotrophic breakdown of OM sourced from the water column (Davies 1975, Rowe et al. 1975). In these models, denitrification was assumed to form the main removal pathway of bio-available nitrogen from the estuarine ecosystem, although the potential role for removal up the foodchain was recognised but largely discounted (Nixon 1981). Later, the importance of productivity by benthic microalgae (BMA) in euphotic sediments was demonstrated (Cadee \& Hegeman 1977, Revsbech et al. 1981, Colijn \& de Jonge 1984, Rizzo \& Wetzel 1985, Sundback 1986), and autotrophic benthic production was shown to have direct and indirect impacts on benthic nutrient fluxes (Andersen et al. 1984, Sundback \& Graneli 1988). These included the direct assimilation of nutrients by autotrophs (Rueter et al. 1986), as well as influencing microbial metabolism through modification of sediment biogeochemistry (e.g. $\mathrm{O}_{2}$ penetration; Revsbech et al. 1980). Elegant mathematical models were subsequently developed vertically integrating the effects of oxygen penetration on benthic microbial processes (Christensen et al. 1989, 1990, Blackburn 1990). The concept of autotrophic benthic production added a new level of complexity to the role of sediments and benthic fluxes in estuarine ecology, especially in shallow systems where euphotic shoals may represent a significant fraction of the total shoal area.

Further complexity was introduced by models describing the influence of bioturbation by macrofauna on sediment biogeochemistry (Aller 1986). Macrofauna can significantly alter the OM distribution, oxygen and redox conditions of the sediment profile (Aller 1988, Kerr \& Corfield 1998, Mortimer et al. 1999), thereby influencing microbial processes and calling into question the validity of models based on vertical zonation alone. Furthermore, grazing interactions by macrofauna, meiofauna and protozoa may stimulate OM mineralisation (Aller 1994, Lillebo et al. 1999). Bioirrigation and excretion are also recognised as important modifying factors for benthic fluxes, often increasing fluxes many-fold over diffusive fluxes alone (Bird et al. 1999, Rysgaard et al. 2000). While infauna were originally seen primarily as 'nutrient pumps', whereby their main role was to facilitate the recycling of nutrients back to the primary producers (Nixon 1981), there is now some evidence that immobilisation of nutrients in biomass may be a significant removal pathway from the microbial loop (van Duyl et al. 1993, Lillebo et al. 1999, Sundback \& Miles 2000). Therefore, both primary and secondary benthic productivity may form another possible fate for nutrients in estuarine ecosystems.

However, many benthic flux studies have omitted the role played by dissolved organic nutrients. A wide variety of dissolved organic nitrogen (DON) compounds are now regarded as important nutrient sources for productivity in coastal ecosystems (Glibert 1993, Bronk et al. 1998) and are seen as important for coastal nitrogen budgets (Hydes et al. 1999). Benthic fluxes of DON are receiving more attention and have been found in some cases to be equally as important as inorganic or gaseous fluxes (Blackburn et al. 1996, Cowan \& Boynton 1996, Hopkinson et al. 1999, Pedersen et al. 1999). In benthic systems, the dynamics of DON cycling are controlled by both autotrophic and heterotrophic processes and their interactions. DON compounds released by autolysis form a vital link in the breakdown of particulate OM and provide low C:N labile substrates for microbial production (Newell et al. 1981, Burdige \& Zheng 1998). DON release may also be associated with excretion of urea by benthic infauna and autotrophic DON release may also occur due to passive release across the cell membrane (Glibert \& Bronk 1994). DON production in pelagic systems has been attributed to 'sloppy feeding' by zooplankton or due to viral infections (Glibert 1993, Bronk et al. 1998), and similar processes may also occur in highly productive sediments (Eyre \& Ferguson 2002). Net uptake of DON by sediments suggests either heterotrophic or autotrophic consumption. Dissolved free amino acids (DFAAs) may form the preferred nitrogen source for bacterial growth due to their low C:N ratio (Kirchman \& Hodson 1986, Rondell et al. 2000), and have been shown to contribute up to $64 \%$ of the nitrogen demand by pelagic bacteria (Keil \& Kirchman 1991). Alternatively, DON compounds may be utilised by bacteria for their carbon skeleton in areas where carbon is limiting to heterotrophic growth (Glibert 1993). Autotrophic organisms may also utilise DON compounds such as urea for a nitrogen source (Bronk et al. 1998). It is clear therefore that DON cycling may be especially important in euphotic sediments with complex autotrophic and heterotrophic interactions.

A new generation of conceptual models for benthic nutrient cycling clearly must include inorganic, 
organic and gaseous nutrient fractions, especially in shallow systems where autotrophic production is present. The purpose of this study was to investigate and characterise diurnal benthic fluxes in euphotic sediments during 4 different seasons along the estuarine gradients of the relatively pristine Sandon estuary, and the nutrient-enriched Brunswick-Simpsons estuary system. These estuaries are shallow and sub-tropical with a high ratio of euphotic sediments along their entire lengths, suggesting that benthic autotrophic production is likely to be a significant factor in benthic, and potentially system-wide, nutrient cycling. Furthermore, high rates of benthic productivity also suggest that dissolved organic nutrient fluxes are likely to be important.

\section{MATERIALS AND METHODS}

Study area. Climate: The Brunswick and Sandon Rivers are located on the northern coast of New South Wales (NSW), Australia (Fig. 1). The climate is controlled by 2 major influences: the sub-tropical high pressure belt during winter-spring (July to October) bringing clear, mainly dry conditions; and easterly monsoonal tradewinds during summer-autumn (November to May) bringing warm, humid conditions. Tropical cyclones may affect the region between January and April, bringing heavy rainfalls (up to $400 \mathrm{~mm} \mathrm{~d}^{-1}$ ) and flooding. Major rainfall events may also occur due to the occurrence of intense low-pressure systems off the NSW coast (East Coast Lows). The region experiences the highest annual rainfall in NSW, with a summer-autumn maximum (wet season), and lowest rainfall occurring during the winter-spring transition (dry season). There is high interannual variation in rainfall due to the influence of the Southern Oscillation on climate in the region: lower than average annual rainfalls occur during El Niño years (atmospheric pressure at Darwin > Tahiti); while greater than average rainfalls occur during La Niña years (atmospheric pressure at Darwin < Tahiti). Cyclone genesis tends to move east during El Niño years, resulting in generally less cyclonic influence on the region's climate. Freshwater flows to the estuaries studied are dominated by large episodic, short-lived inputs during summer and very low flow in winter. The Brunswick estuary catchment receives approximately 1.5 times the average annual rainfall of the Sandon estuary catchment. The current study period spanned a range of climatic conditions, with 1997 and 1998 receiving mostly less than median rainfall while 1999 received mostly greater than median rainfall. There were no floods during this period; however, several high flow events were sampled during February and March 1999.
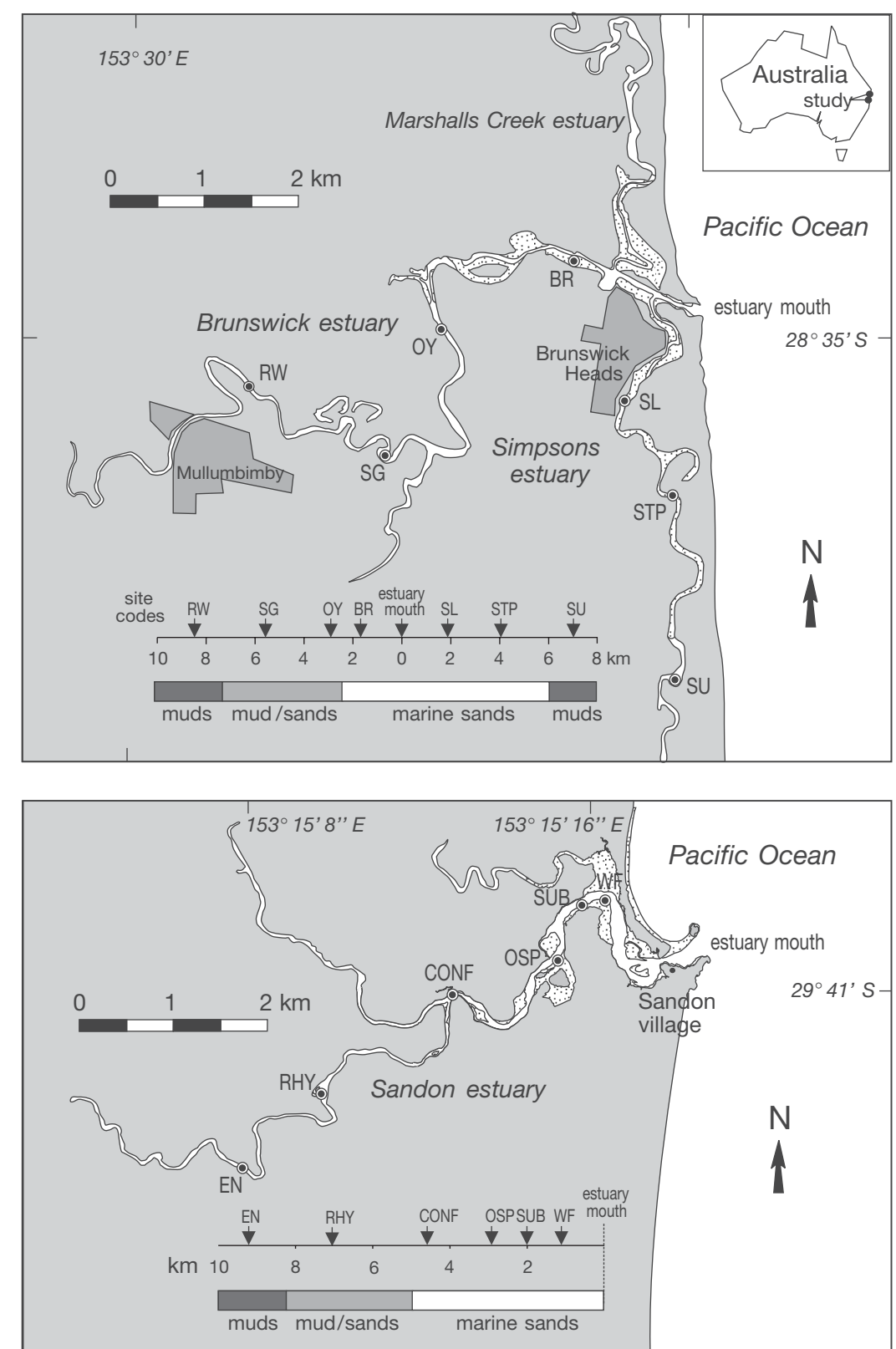

Fig. 1. The Brunswick-Simpsons estuary system and Sandon estuary, northern New South Wales, Australia, showing the locations of study sites 
The Brunswick-Simpsons estuary system: The Brunswick-Simpsons estuary system has a total catchment area of approximately $218 \mathrm{~km}^{2}$. The Brunswick estuary forms the main arm of the system, while the Simpsons estuary forms the south arm and joins the main arm about $500 \mathrm{~m}$ from the ocean entrance. Marshalls Creek estuary forms the north arm of the system, joining the main arm about $500 \mathrm{~m}$ upstream of the Simpsons estuary. Up to $75 \%$ of the Brunswick-Simpsons estuary catchment has been cleared for agriculture and grazing, and $75 \%$ of the estuary shoreline has been modified. The main arm, Brunswick estuary, receives direct effluent discharges from 2 sewage treatment plants (STPs): 1 at Mullumbimby in the upper estuary (10.5 km from the estuary mouth), and 1 at Ocean Shores in the lower estuary $(3 \mathrm{~km}$ from the estuary mouth). The south arm, Simpsons estuary, receives sewage effluent from one STP located $3.5 \mathrm{~km}$ from the estuary mouth. Combined sewage discharges from all 3 plants dominated nitrogen and phosphorus loadings to the estuary system during the study period. The relative importance of STP loadings increases during low flow conditions (Ferguson et al. 2004). The main arm Brunswick estuary also receives storm water runoff from the townships of Mullumbimby $\left(2.5 \mathrm{~km}^{2}\right)$. Urban runoff from Brunswick Heads $\left(0.08 \mathrm{~km}^{2}\right)$ is distributed equally to the lower main arm and south arm estuaries.

The Sandon estuary: The Sandon River has a catchment of approximately $100 \mathrm{~km}^{2}$. Due to low freshwater inputs for much of the year, the head of the Sandon estuary rarely drops below a salinity of 15, and during the dry season the head of the estuary may reach salinities of 30. Salinity is often depressed along the middle stretches of the estuary, indicating groundwater inputs from extensive low-lying swamps adjacent to this part of the estuary. In contrast to the Brunswick River, there is no urban or agricultural development in the Sandon catchment. Main disturbances are small-scale logging operations and sparse cattle grazing in the upper catchment.
Site selection. A pilot survey of sediment carbon, nitrogen and phosphorus was undertaken to broadly characterise sediment quality of subtidal shoals along the estuarine gradient of the Brunswick-Simpsons estuary system and the Sandon estuary. Three basic sediment types were identified: (1) fine-grained, organic-rich muds in the upper estuary; (2) organicrich, aeolian/fluvial sands in the middle estuary; and (3) organic-poor, marine sands in the lower estuary. There was little cross-sectional variability in the upper and lower estuaries, while in the middle estuaries variability between left and right banks tended to be much higher.

Sites were chosen along the estuarine gradients of the Brunswick-Simpsons and Sandon estuaries in an attempt to broadly characterise zones of common sediment and water quality conditions (Fig. 1) in the upper, middle and lower estuary during average flow. The study estuaries may be flushed fresh to the mouth during high flow events (Eyre 2000), thus all sites may be periodically subject to freshwater conditions and sediment scouring. Tides along the sub-tropical Australian east coast are seme-diurnal and tidal range is up to $2 \mathrm{~m}$ during spring tides, and $<1 \mathrm{~m}$ during neap tides. Sample sites were established on subtidal shoals within $10 \mathrm{~m}$ of the bank and at a mean depth of $0.75 \mathrm{~m}$ at low tide. These shoals are within the photic zone throughout the tidal cycle and therefore represent potentially the most productive subtidal sediments at each site. In the middle estuaries, where sediment quality was more variable, sites were chosen on shoals with the highest carbon content as these were likely to represent areas of maximal benthic metabolism. Sites were demarcated by $50 \mathrm{~mm}$ PVC poles so that the same location $( \pm 2 \mathrm{~m})$ was sampled during each season.

Benthic process measurements. Benthic metabolism and sediment/water nutrient fluxes were measured using on-site sediment core incubations which maintain the diel and diurnal rhythms of the benthic communities under close to in situ light and temperature conditions. Triplicate sediment cores (approximately

Table 1. Analytical methods, associated detection limits, and collection/storage errors for dissolved nutrients. CV: coefficient of variation (SD/mean); NEDD: N-(1-naphthyl)ethylenediamine dihydrochloride (NED); nd: not determined

\begin{tabular}{|c|c|c|c|c|}
\hline Nutrient form & Symbol & Method & Detection limit $\left(\mu \mathrm{g} \mathrm{l}^{-1}\right)$ & $\mathrm{CV}(\%)$ \\
\hline Total dissolved nitrogen & TDN & Persulphate digestion & 5 & 4.1 \\
\hline Nitrite & $\mathrm{NO}_{2}^{-}$ & Cadmium reduction + sulphanilamide & 2 & 2.8 \\
\hline Nitrate & $\mathrm{NO}_{3}^{-}$ & + NEDD & nd & 3.6 \\
\hline Ammonium & $\mathrm{NH}_{4}^{+}$ & Hypochlorite + phenol & 5 & 5.1 \\
\hline Dissolved organic nitrogen & DON & $\mathrm{TDN}-\mathrm{NO}_{\mathrm{x}}+\mathrm{NH}_{4}^{+}$ & nd & 19 \\
\hline Total dissolved phosphorus & TDP & Persulphate digestion & 5 & 3.5 \\
\hline Dissolved inorganic phosphorus & DIP & Ascorbic acid + molybdate blue & 2 & 2.3 \\
\hline Dissolved organic phosphorus & DOP & TDP - DIP & nd & 5.1 \\
\hline Silica & $\mathrm{Si}$ & Stannous chloride & 5 & 3.1 \\
\hline
\end{tabular}


$20 \mathrm{~cm}$ long) including overlying water (approximately $2.3 \mathrm{l}$ ) were collected from each site in $50 \mathrm{~cm}$ long, $95 \mathrm{~mm}$ inner diameter clear acrylic pipes using a remote coring device. Cores were examined to ensure that the bulk of the sediment surface was intact and discarded if disturbed. Cores were shaded and transported to the incubation site, where the overlying water was removed and gently replaced (ensuring no resuspension of the sediment surface) with water collected from the sample site at high tide and filtered through GF/C glass-fibre filters to remove zooplankton and large phytoplankton. They were then sealed airtight with a clear acrylic lid (including sample ports and a Teflon stir bar suspended approximately $15 \mathrm{~cm}$ from the sediment surface), placed in a floating incubation cradle in the estuary (with the sediment surface at a depth of approximately $50 \mathrm{~cm}$ ) and allowed to equilibrate to temperature and light conditions for approximately $3 \mathrm{~h}$. Stirring rate was adjusted to just below the threshold for resuspension. Whilst this may not truly represent in situ conditions where sediment resuspension may occur readily due to tidal currents and wind waves, it was considered appropriate since the focus of the study was to investigate benthic microbial processes rather than attempt to quantify in situ fluxes.

Incubations were run over $36 \mathrm{~h}$, with the first samples taken at sunset on the day of core collection and subsequent samples taken at midnight, dawn, midday, sunset and dawn. This was done to ensure that benthic communities were kept as fresh as possible and in step with their diel light/dark cycles. At each sample time, dissolved oxygen concentrations $\left( \pm 0.01 \mathrm{mg} \mathrm{l}^{-1}\right)$ and $\mathrm{pH}$ $( \pm 0.002 \mathrm{pH}$ units $)$ were measured directly via a port in the lid using a YSI 5000 BOD probe and Denver $\mathrm{pH}$ probe, respectively. Samples for alkalinity and dissolved nutrients were withdrawn via a separate port and filtered through a $0.45 \mu \mathrm{m}$ cellulose acetate filter into $10 \mathrm{ml}$ acid-rinsed and sample-rinsed polyethylene vials. As samples were taken, an equal amount of replacement water was automatically drawn into the incubation chamber from a reservoir of filtered site water. Samples for alkalinity and silicate were immediately refrigerated at $4{ }^{\circ} \mathrm{C}$ and nutrient samples were frozen at $-20^{\circ} \mathrm{C}$. A blank of each water type was also sampled for dissolved oxygen and $\mathrm{pH}$.

Use of blanks. This study only used blanks of each water type to assess potential microbial activity in the water based on $\mathrm{O}_{2}$ concentration changes. The filtration of replacement water using GF/C filters was found to remove between 95 and $98 \%$ of phytoplankton present in the water (based on fluorometric measurements). While no assessment was made of the removal efficiency for bacteria, blank $\mathrm{O}_{2}$ measurements showed that $\mathrm{O}_{2}$ concentration changes were minimal
$(<2 \%)$ in the filtered water, and it was therefore assumed that most of the microbial activity of the water was removed by filtration.

Benthic flux calculations. Benthic fluxes of nutrients across the sediment-water interface were calculated using the following formula:

$$
\mathrm{BF}=\left(\left[C_{t_{1}}-C_{t_{0}}\right] \times V / \mathrm{SA}\right) / T
$$

where $\mathrm{BF}=$ benthic flux of nutrient $\left(\mu \mathrm{mol} \mathrm{m} \mathrm{m}^{-2} \mathrm{~h}^{-1}\right)$, $C_{t_{0}}=$ nutrient conc. $\left(\mu \mathrm{mol} \mathrm{l^{-1 }}\right)$ in overlying water at the start of time period, $C_{t_{1}}=$ nutrient conc. $\left(\mu \mathrm{mol} \mathrm{l^{-1 }}\right)$ in overlying water at the end of time period, $V=$ volume of overlying water (l) in the incubation chamber, $\mathrm{SA}=$ surface area of sediment $\left(\mathrm{m}^{2}\right)$ in the incubation chamber, and $T=$ time $(\mathrm{h})$.

Dark flux rates were calculated using concentration data from the first dark period of the incubation (i.e. sunset to dawn), and net light fluxes were calculated using the second $12 \mathrm{~h}$ (dawn to sunset). Gross benthic primary productivity was calculated by subtracting dark $\mathrm{O}_{2} / \mathrm{TCO}_{2}$ flux rates (respiration) from net light rates (respiration + productivity). Net daily flux rates were calculated as the difference between concentrations at the start and the end of the diurnal period (sunset to sunset). Diurnal productivity/respiration $(\mathrm{p} / \mathrm{r})$ values were calculated as the gross diurnal productivity divided by gross diurnal respiration.

Sediment porewater profiles. An extra sediment core was collected at each site for the extraction of porewater during the winter, spring and summer sample runs. Cores were sectioned at depths of $0-1,1-2$, $2-3,4-5$, and $9-10 \mathrm{~cm}$ in an $\mathrm{N}_{2}$ filled glove bag. At each depth, half the sample was frozen at $-20^{\circ} \mathrm{C}$ for 'lysable' porewater analysis and the other half was kept refrigerated at $4^{\circ} \mathrm{C}$ for 'free' porewater analysis. Porewater was extracted within $24 \mathrm{~h}$ through GF/F and $0.45 \mu \mathrm{m}$ cellulose acetate filters under a vacuum of 0.4 atm. Samples were then frozen at $-20^{\circ} \mathrm{C}$ until analysis.

Nutrient analysis. Ammonium $\left(\mathrm{NH}_{4}{ }^{+}\right)$, nitrite $\left(\mathrm{NO}_{2}{ }^{-}\right)$, nitrate + nitrite $\left(\mathrm{NO}_{\mathrm{x}}\right)$, phosphorus (DIP), silica (Si) and total dissolved nitrogen (TDN) and phosphorus (TDP) were analysed using Lachat ${ }^{\mathrm{TM}}$ Flow Injection Analysis following standard colourmetric methods (Valderamma 1981, Lachat 1994). Dissolved organic nitrogen (DON) and dissolved organic phosphorus (DOP) were determined by difference (Table 1). Analytical accuracy for nutrient analysis was maintained by running standard additions of certified laboratory standards in both Milli-Q and artificial seawater every 20 samples. Samples from each incubation time series were run in sequence to minimise error in flux calculations introduced by instrument drift. Errors associated with collection and storage were assessed by collecting every tenth sample during estuarine sampling runs in tripli- 
cate (Ferguson et al. 2004), with the error expressed as the average \% CV (coefficient of variation, SD/mean) of all triplicates.

Denitrification. Denitrification measurements were made at sites in the upper, middle and lower Brunswick estuary during the spring-dry and summerwet sample runs. Samples were collected in triplicate at the same time as nutrient samples by allowing water to flow from the sample port into $7 \mathrm{ml}$ glass vials until overflowing. Samples were killed with $20 \mu$ of saturated $\mathrm{HgCl}_{2}$ solution, capped with gas-tight glass stoppers and stored submerged in water at ambient temperature until analysis. $\mathrm{N}_{2}$ :Ar ratios in samples were measured using membrane inlet mass spectrometry (Kana et al. 1994) with modifications described by Eyre \& Ferguson (2002). Denitrification was estimated by linear regression of concentration versus time plots as described above for other nutrient fluxes.

\section{RESULTS}

Benthic nitrogen fluxes. Light and dark sediment/ water fluxes (mean \pm SD) of DIN and DON along the Brunswick, Simpsons and Sandon estuaries for each site are presented in Table 2. These means are calculated from triplicates taken at 4 distinct seasons throughout the year (i.e. $n=12$ ) and hence integrate a degree of spatial and temporal variability. DON fluxes formed an important component of overall fluxes throughout the study. In general, nitrogen fluxes were greatest in the organic-rich muds towards the head of each estuary and diminished towards the marine sands of the lower estuary. There were noticeable differences in both the direction and rate of nitrogen fluxes between the light and dark; however, these differences were extremely variable between estuaries, sites and seasons. Light/dark differences were accentuated in cores with high benthic productivity, with shifts in direction and rate occurring primarily in step with the light/dark cycle.

Autumn wet season. During the autumn wet season, nitrogen fluxes were dominated by uptakes in all 3 estuaries with the exception of DON fluxes, which were primarily effluxes. Ammonium uptakes in the Brunswick and Simpsons estuaries were generally enhanced during the light (up to $-300 \mu \mathrm{mol} \mathrm{m} \mathrm{m}^{-2} \mathrm{~h}^{-1}$ ), while the opposite trend occurred in the Sandon estuary with generally higher uptakes occurring during the dark (up to $-40 \mu \mathrm{mol} \mathrm{m} \mathrm{m}^{-2} \mathrm{~h}^{-1}$ ). Nitrate uptakes were variable, with no clear trends emerging between light and dark phases. In general, nitrate was taken up by sediments throughout the study at constant rates governed by nitrate concentrations in the overlying water (up to $-80 \mu \mathrm{mol} \mathrm{m} \mathrm{m}^{-2} \mathrm{~h}^{-1}$ ). Thus, the depletion of nitrate in the overlying water throughout the initial dark phase of the incubation influenced nitrate fluxes during the subsequent light phase. DON effluxes were generally enhanced during the light phase in the Brunswick and Simpsons estuaries (up to $110 \mu \mathrm{mol} \mathrm{m}{ }^{-2}$ $\mathrm{h}^{-1}$ ), with the opposite trend occurring in the Sandon estuary, where dark fluxes were generally highest (up to $60 \mu \mathrm{mol} \mathrm{m} \mathrm{m}^{-2} \mathrm{~h}^{-1}$ ).

Winter dry season. Benthic fluxes of both nitrogen and phosphorus during this sample run were dominated by uptakes in all 3 estuaries. Enhanced uptake of ammonium was observed during the light in the Brunswick estuary (up to $-110 \mu \mathrm{mol} \mathrm{m} \mathrm{m}^{-2} \mathrm{~h}^{-1}$ ), while in both the Simpsons and Sandon estuaries uptakes tended to be greatest during the dark (up to $-48 \mu \mathrm{mol}$ $\mathrm{m}^{-2} \mathrm{~h}^{-1}$ ) and there were even slight ammonium effluxes during the light at some sites (up to $12 \mu \mathrm{mol}$ $\mathrm{m}^{-2} \mathrm{~h}^{-1}$ ). There was also enhanced uptake of nitrate

Table 2. Dark and light fluxes of dissolved inorganic nitrogen, organic nitrogen and dinitrogen gas (mean \pm SD) at the study sites over the study period. Fluxes presented here integrate a degree of spatial (at approximately $1 \mathrm{~m}^{-2}$ ) and temporal (seasonal)

variability. Details of variability between sample times are given in the text. All units are $\mu \mathrm{mol} \mathrm{m}^{-2} \mathrm{~h}^{-1}$; $\mathrm{n}=12$ for each site

\begin{tabular}{|c|c|c|c|c|c|c|c|c|}
\hline Estuary & Site & $\mathrm{NH}_{4}{ }^{+}$dark & $\mathrm{NH}_{4}{ }^{+}$light & $\mathrm{NO}_{3}^{-}$dark & $\mathrm{NO}_{3}{ }^{-}$light & DON dark & DON light & $\mathrm{N}_{2}$ dark \\
\hline \multirow[t]{4}{*}{ Brunswick } & RW & $52 \pm 121$ & $-63 \pm 126$ & $-50 \pm 59$ & $-43 \pm 36$ & $6 \pm 66$ & $66 \pm 70$ & $31 \pm 32$ \\
\hline & SG & $-5 \pm 52$ & $-65 \pm 59$ & $-32 \pm 19$ & $-47 \pm 43$ & $6 \pm 73$ & $19 \pm 45$ & $262 \pm 364$ \\
\hline & OY & $78 \pm 101$ & $-39 \pm 68$ & $-33 \pm 24$ & $-26 \pm 13$ & $-7 \pm 27$ & $64 \pm 151$ & - \\
\hline & $\mathrm{BR}$ & $-24 \pm 16$ & $-15 \pm 16$ & $-9 \pm 15$ & $-27 \pm 17$ & $-7 \pm 56$ & $7 \pm 52$ & $42 \pm 23$ \\
\hline \multirow[t]{3}{*}{ Simpsons } & SU & $9 \pm 49$ & $-27 \pm 52$ & $-19 \pm 30$ & $-16 \pm 26$ & $-28 \pm 49$ & $-30 \pm 47$ & - \\
\hline & STP & $-15 \pm 33$ & $-18 \pm 24$ & $-8 \pm 9$ & $-13 \pm 15$ & $-26 \pm 33$ & $5 \pm 36$ & - \\
\hline & $\mathrm{SL}$ & $-12 \pm 19$ & $-28 \pm 57$ & $-9 \pm 10$ & $-4 \pm 6$ & $-4 \pm 34$ & $3 \pm 47$ & - \\
\hline \multirow[t]{6}{*}{ Sandon } & EN & $-22 \pm 21$ & $-18 \pm 21$ & $-14 \pm 14$ & $-11 \pm 7$ & $6 \pm 74$ & $5 \pm 60$ & - \\
\hline & RHY & $-12 \pm 19$ & $4 \pm 12$ & $-7 \pm 4$ & $-3 \pm 6$ & $-32 \pm 74$ & $-4 \pm 35$ & - \\
\hline & $\mathrm{CON}$ & $-9 \pm 14$ & $-3 \pm 11$ & $-5 \pm 4$ & $-2 \pm 2$ & $11 \pm 39$ & $-29 \pm 93$ & - \\
\hline & OSP & $-4 \pm 10$ & $1 \pm 12$ & $-10 \pm 6$ & $-5 \pm 7$ & $9 \pm 27$ & $10 \pm 49$ & - \\
\hline & SUB & $-13 \pm 7$ & $0 \pm 6$ & $-8 \pm 6$ & $-6 \pm 5$ & $7 \pm 21$ & $-4 \pm 26$ & - \\
\hline & WF & $-5 \pm 10$ & $-2 \pm 11$ & $-10 \pm 7$ & $-6 \pm 7$ & $-11 \pm 47$ & $14 \pm 33$ & - \\
\hline
\end{tabular}


during the light at most sites in all 3 estuaries (up to $-100 \mu \mathrm{mol} \mathrm{m} \mathrm{m}^{-2} \mathrm{~h}^{-1}$ in the Brunswick estuary), with the exception of subtidal shoals in the lower Sandon estuary (Sites OSP and WF; see Fig. 1) and the upper Brunswick estuary, where uptake was greatest during the dark (up to $-150 \mu \mathrm{mol} \mathrm{m} \mathrm{m}^{-2} \mathrm{~h}^{-1}$ at Site RW). DON fluxes were highly variable in direction and magnitude but overall were dominated by uptakes (up to $-125 \mu \mathrm{mol} \mathrm{m} \mathrm{m}^{-2} \mathrm{~h}^{-1}$ ) during both light and dark phases, apart from effluxes in some cores along the Brunswick and Sandon estuaries (up to $60 \mu \mathrm{mol} \mathrm{m} \mathrm{m}^{-2} \mathrm{~h}^{-1}$ ).

Spring dry season. Fluxes during this sample run were the smallest recorded during this study, and tended to be highly regulated by the light/dark cycle. Ammonium fluxes in the Brunswick and Simpsons estuaries were almost ubiquitously effluxes during the dark (up to $75 \mu \mathrm{mol} \mathrm{m} \mathrm{m}^{-2} \mathrm{~h}^{-1}$ ) and uptakes during the light (up to $-50 \mu \mathrm{mol} \mathrm{m} \mathrm{m}^{-2} \mathrm{~h}^{-1}$ ), while ammonium uptakes dominated in the Sandon estuary and tended to be greatest during the dark (up to $-52 \mu \mathrm{mol} \mathrm{m} \mathrm{m}^{-2} \mathrm{~h}^{-1}$ ). As with all sample runs, nitrate was taken up by the sediments at a relatively constant rate throughout the incubations, although there was some enhanced uptake during the light observed in the lower Brunswick estuary. Nitrate uptakes were highest in the lower Brunswick estuary (up to $-30 \mu \mathrm{mol} \mathrm{m} \mathrm{m}^{-2} \mathrm{~h}^{-1}$ ) due to higher ambient nitrate concentrations in the water column at this time. DON fluxes in the Brunswick and Simpson estuaries tended to mirror ammonium fluxes, with uptakes at night (up to $-70 \mu \mathrm{mol} \mathrm{m} \mathrm{m}^{-2} \mathrm{~h}^{-1}$ ) and effluxes during the day peaking in the highly productive sediments of the lower estuaries (up to $100 \mu \mathrm{mol}$ $\mathrm{m}^{-2} \mathrm{~h}^{-1}$ ). DON fluxes in the Sandon estuary were dominated by large uptakes during the dark (up to $-175 \mu \mathrm{mol} \mathrm{m} \mathrm{m}^{-2} \mathrm{~h}^{-1}$ ) with reduced uptakes or effluxes during the light (up to $75 \mu \mathrm{mol} \mathrm{m} \mathrm{m}^{-2} \mathrm{~h}^{-1}$ ).

Summer wet season. In contrast to the preceding spring run, this sample run was characterised by the largest benthic fluxes recorded during this study. Large ammonium effluxes were recorded during the dark in the middle and upper Brunswick estuary (up to $310 \mu \mathrm{mol} \mathrm{m}{ }^{-2} \mathrm{~h}^{-1}$ ); however, fluxes were much reduced or switched to uptakes during the light (up to $-190 \mu \mathrm{mol} \mathrm{m} \mathrm{m}^{-2} \mathrm{~h}^{-1}$ ). Similar patterns were observed in the Simpsons estuary although rates were significantly lower (from 110 to $-120 \mu \mathrm{mol} \mathrm{m} \mathrm{m}^{-2} \mathrm{~h}^{-1}$ ). The opposite patterns occurred in the Sandon estuary, where ammonium fluxes were much smaller (from 7 to $-45 \mu \mathrm{mol} \mathrm{m}{ }^{-2}$ $\mathrm{h}^{-1}$ ) and were dominated by uptake during the dark at most sites (excluding Site WF) and effluxed slightly during the light. Nitrate was taken up during the light and dark in all estuaries with some light-enhanced uptake in the Brunswick estuary. Total depletion of ambient nitrate by the end of the dark phase in the Sandon incubations resulted in no further fluxes dur- ing the subsequent light phase. DON fluxes in the Brunswick estuary were dominated by large effluxes during the light (up to $310 \mu \mathrm{mol} \mathrm{m} \mathrm{m}^{-2} \mathrm{~h}^{-1}$ ) and reduced effluxes during the dark (up to $50 \mu \mathrm{mol} \mathrm{m}^{-2} \mathrm{~h}^{-1}$ ). In contrast, DON fluxes in the Simpsons estuary were almost all uptakes, with highest rates during the dark in the middle and upper estuary (up to $-140 \mu \mathrm{mol} \mathrm{m} \mathrm{m}^{-2} \mathrm{~h}^{-1}$ ) and during the day in the lower estuary (up to $-80 \mu \mathrm{mol} \mathrm{m} \mathrm{m}^{-2} \mathrm{~h}^{-1}$ ).

Porewater profiles. Free and lysable porewater ammonium profiles for the Brunswick and Simpsons estuaries during the spring dry season are presented in Fig. 2. All sites displayed an increase of porewater ammonium towards the sediment surface, with the bulk of the increase being in the lysable fraction. This increase was concomitant with an increase in redox potential in the surface layers of sediment. There was also an increase in lysable ammonium with depth at the upper estuary sites, coinciding with a sharp reduction in redox potential below $-100 \mathrm{mV}$. Similar trends were observed during other seasons and in the Sandon estuary (data not presented).

\section{DISCUSSION}

\section{Stoichiometry of dark fluxes}

The relationships between benthic metabolism (measured as $\mathrm{TCO}_{2}$ flux) and DIN fluxes during the dark for the 3 study systems over the 4 seasons are presented in Fig. 3 ( $\mathrm{TCO}_{2}$ data from Ferguson et al. 2003). In general, the upper limits of dark $\mathrm{NH}_{4}{ }^{+}$(and DIN) effluxes were constrained by the expected mineralisation of DIN due to the breakdown of 'Redfield' algal material; however, the vast majority of fluxes fell short of this relationship and were dominated by uptakes. DIN uptakes were generally constrained by the theoretical assimilation of DIN by bacteria assuming a C:N ratio of 5 (Valiela 1995, Rondell et al. 2000). With the exception of large effluxes recorded in the middle to upper Brunswick during summer, the relative magnitude of dark fluxes dropped off markedly at respiration rates greater than $1000 \mu \mathrm{mol} \mathrm{CO}_{2} \mathrm{~m}^{-2} \mathrm{~h}^{-1}$. Similar shortfalls in DIN relative to respiration have been previously interpreted as the permanent or temporary removal of nitrogen due to denitrification, immobilsation into microbial biomass or incorporation into higher trophic levels (Banta et al. 1994, Berelson et al. 1998, Hammond et al. 1999). Alternatively, the C:N of OM undergoing mineralisation may be higher than the assumed Redfield ratio. Denitrification measurements in the Brunswick estuary showed that denitrification rates were mostly insufficient to account for the DIN deficit relative to $\mathrm{CO}_{2}$ effluxes during the dark, sug- 

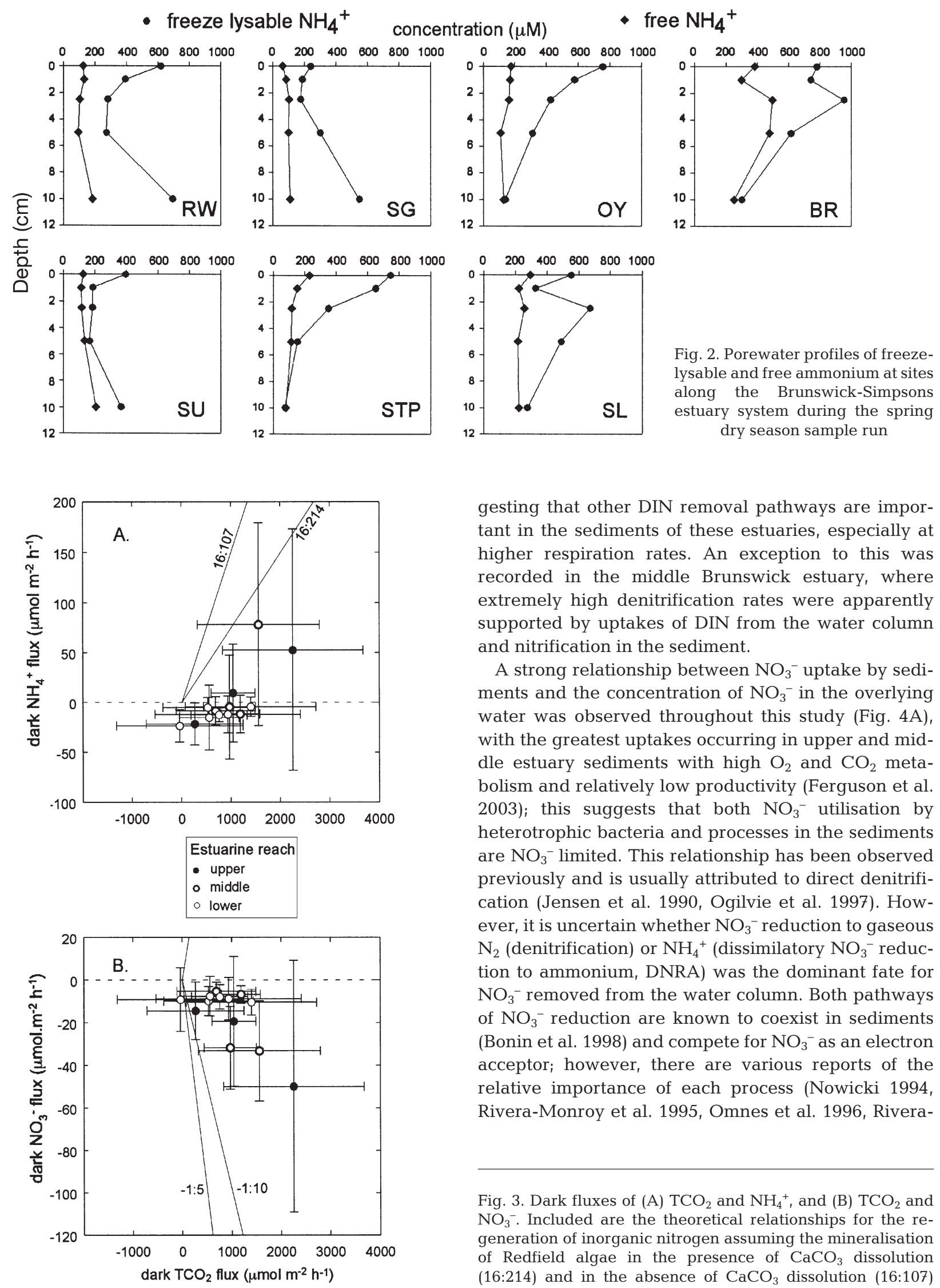

gesting that other DIN removal pathways are important in the sediments of these estuaries, especially at higher respiration rates. An exception to this was recorded in the middle Brunswick estuary, where extremely high denitrification rates were apparently supported by uptakes of DIN from the water column and nitrification in the sediment.

A strong relationship between $\mathrm{NO}_{3}{ }^{-}$uptake by sediments and the concentration of $\mathrm{NO}_{3}{ }^{-}$in the overlying water was observed throughout this study (Fig. 4A), with the greatest uptakes occurring in upper and middle estuary sediments with high $\mathrm{O}_{2}$ and $\mathrm{CO}_{2}$ metabolism and relatively low productivity (Ferguson et al. 2003); this suggests that both $\mathrm{NO}_{3}{ }^{-}$utilisation by heterotrophic bacteria and processes in the sediments are $\mathrm{NO}_{3}{ }^{-}$limited. This relationship has been observed previously and is usually attributed to direct denitrification (Jensen et al. 1990, Ogilvie et al. 1997). However, it is uncertain whether $\mathrm{NO}_{3}{ }^{-}$reduction to gaseous $\mathrm{N}_{2}$ (denitrification) or $\mathrm{NH}_{4}{ }^{+}$(dissimilatory $\mathrm{NO}_{3}{ }^{-}$reduction to ammonium, DNRA) was the dominant fate for $\mathrm{NO}_{3}{ }^{-}$removed from the water column. Both pathways of $\mathrm{NO}_{3}{ }^{-}$reduction are known to coexist in sediments (Bonin et al. 1998) and compete for $\mathrm{NO}_{3}{ }^{-}$as an electron acceptor; however, there are various reports of the relative importance of each process (Nowicki 1994, Rivera-Monroy et al. 1995, Omnes et al. 1996, Rivera-

Fig. 3. Dark fluxes of (A) $\mathrm{TCO}_{2}$ and $\mathrm{NH}_{4}{ }^{+}$, and (B) $\mathrm{TCO}_{2}$ and $\mathrm{NO}_{3}{ }^{-}$. Included are the theoretical relationships for the regeneration of inorganic nitrogen assuming the mineralisation of Redfield algae in the presence of $\mathrm{CaCO}_{3}$ dissolution (16:214) and in the absence of $\mathrm{CaCO}_{3}$ dissolution $(16: 107)$ 

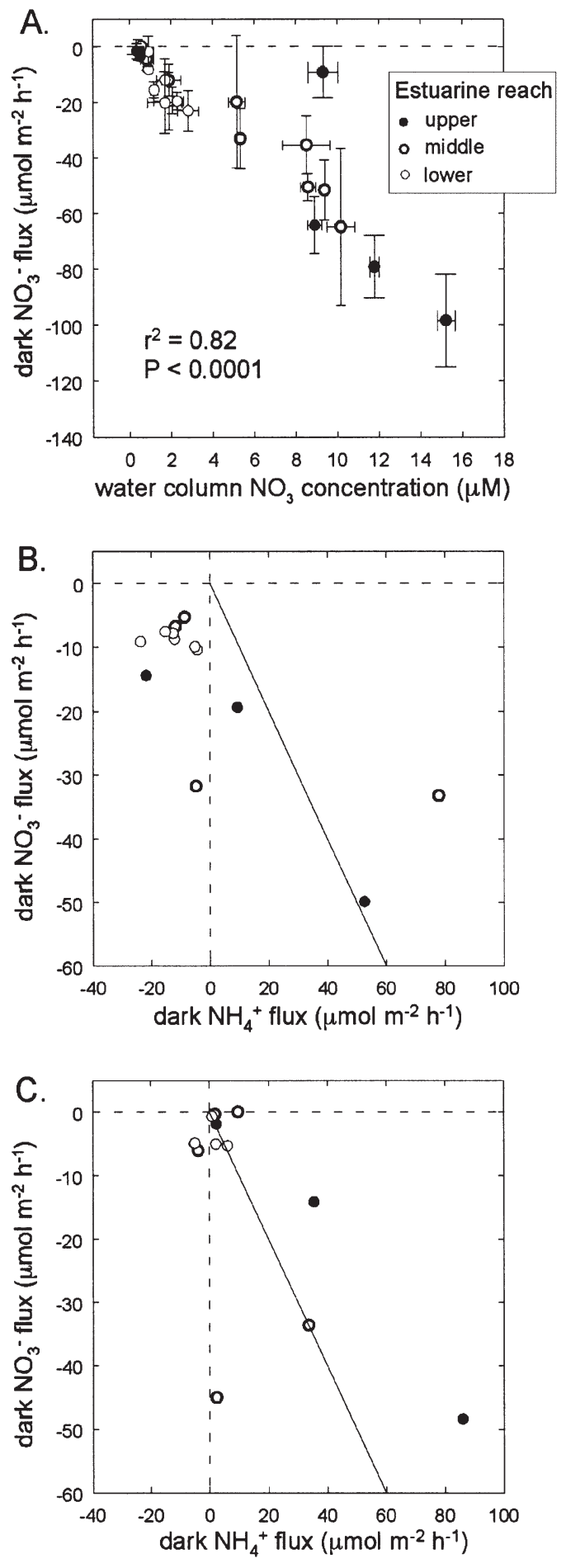

Fig. 4. (A) Relationship between dark $\mathrm{NO}_{3}{ }^{-}$flux and ambient $\mathrm{NO}_{3}{ }^{-}$concentrations in the overlying water. (B,C) Dark fluxes of $\mathrm{NH}_{4}{ }^{+}$and $\mathrm{NO}_{3}{ }^{-}$during (B) the first night of incubation when $\mathrm{O}_{2}$ concentrations had not varied by more than $20 \%$ from ambient, and (C) the second night of incubation when $\mathrm{O}_{2}$ concentrations had generally dropped by more than $40 \%$ from ambient. Relationship between $\mathrm{NH}_{4}{ }^{+}$and $\mathrm{NO}_{3}{ }^{-}$fluxes during the second night is closer to that expected for dissimilatory $\mathrm{NO}_{3}{ }^{-}$reduction to ammonium (DNRA)
Monroy \& Twilley 1996, Rysgaard et al. 1996, Barnes \& Owens 1998, Bonin et al. 1998). As $\mathrm{NH}_{4}{ }^{+}$is the product of DNRA, it follows that $\mathrm{NO}_{3}{ }^{-}$uptakes should be accompanied by an efflux of $\mathrm{NH}_{4}{ }^{+}$at a ratio of $1: 1$ if this is the dominant process and there are no other processes consuming or producing $\mathrm{NH}_{4}{ }^{+}$. Fig. 4B shows that during the first night of incubation, when oxygen concentrations generally dropped below $80 \%$ of ambient, $\mathrm{NO}_{3}{ }^{-}$and $\mathrm{NH}_{4}{ }^{+}$fluxes were dominated by uptakes of both $\mathrm{N}$ species at the majority $(75 \%)$ of sites. However, during the second night, when oxygen concentrations were more depleted, there was a shift at $85 \%$ of sites towards the relationship expected for DNRA (Fig. 4C), suggesting that this form of benthic metabolism becomes more important under low oxygen conditions. This shift may be due to a combination of nitrification inhibition caused by $\mathrm{O}_{2}$ depletion and subsequent nitrate depletion by denitrifiers and the net increase in $\mathrm{C}: \mathrm{N}$ of $\mathrm{OM}$, both of which may favour DNRA over denitrification (Smith et al. 1982, King \& Nedwell 1987, Rivera-Monroy et al. 1995). This has important implications for the upper and middle Brunswick estuary, which experiences hypoxic conditions in the water column due to the breakdown of algal detritus from large pelagic blooms throughout the year.

\section{Light fluxes}

There was commonly an uptake (or reduced efflux) of $\mathrm{NH}_{4}{ }^{+}$in the light, whilst uptakes of $\mathrm{NO}_{3}^{-}$were almost ubiquitously linear throughout both the light and dark phase at all sites. These patterns suggest 2 possible explanations: (1) that $\mathrm{NO}_{3}^{-}$is the primary source of nitrogen for benthic BMA and is supplemented by $\mathrm{NH}_{4}{ }^{+}$during the light, or (2) that $\mathrm{NH}_{4}{ }^{+}$is the preferred nitrogen source and $\mathrm{NO}_{3}{ }^{-}$uptake is related to some other benthic process such as denitrification or dissimilatory reduction of $\mathrm{NO}_{3}^{-}$to $\mathrm{NH}_{4}{ }^{+}$ (see 'Stoichiometry of dark fluxes' above). Most evidence, however, points to the likelihood of the second scenario. $\mathrm{NH}_{4}{ }^{+}$is thought to be the preferred nitrogen source for marine autotrophs since its assimilation is energetically favoured (Lipschultz et al. 1986, Glibert 1993, Bronk et al. 1998, O'Donohue et al. 2000). In contrast, $\mathrm{NO}_{3}^{-}$must be reduced by the algae before assimilation in 2 reactions involving nitrate and nitrite reductase enzymes and $\mathrm{NADPH}_{2}$ as an electron donor. The assimilation rate of $\mathrm{NO}_{3}{ }^{-}$by aquatic photoautotrophs (in particular diatoms) is regulated by the enzymatic activity of nitrate reductase, which peaks during the middle of the day due to the endothermic nature of the reactions involved (Falkowski \& Raven 1997). It is therefore likely that $\mathrm{NO}_{3}{ }^{-}$ 
fluxes would have shown some signal of increased uptake during the light if uptakes were related to benthic productivity. This did occur at some sites in the middle and lower estuarine sediments, where $\mathrm{NH}_{4}{ }^{+}$concentrations in the overlying water were low and perhaps limiting; however, the implied rates were minimal.
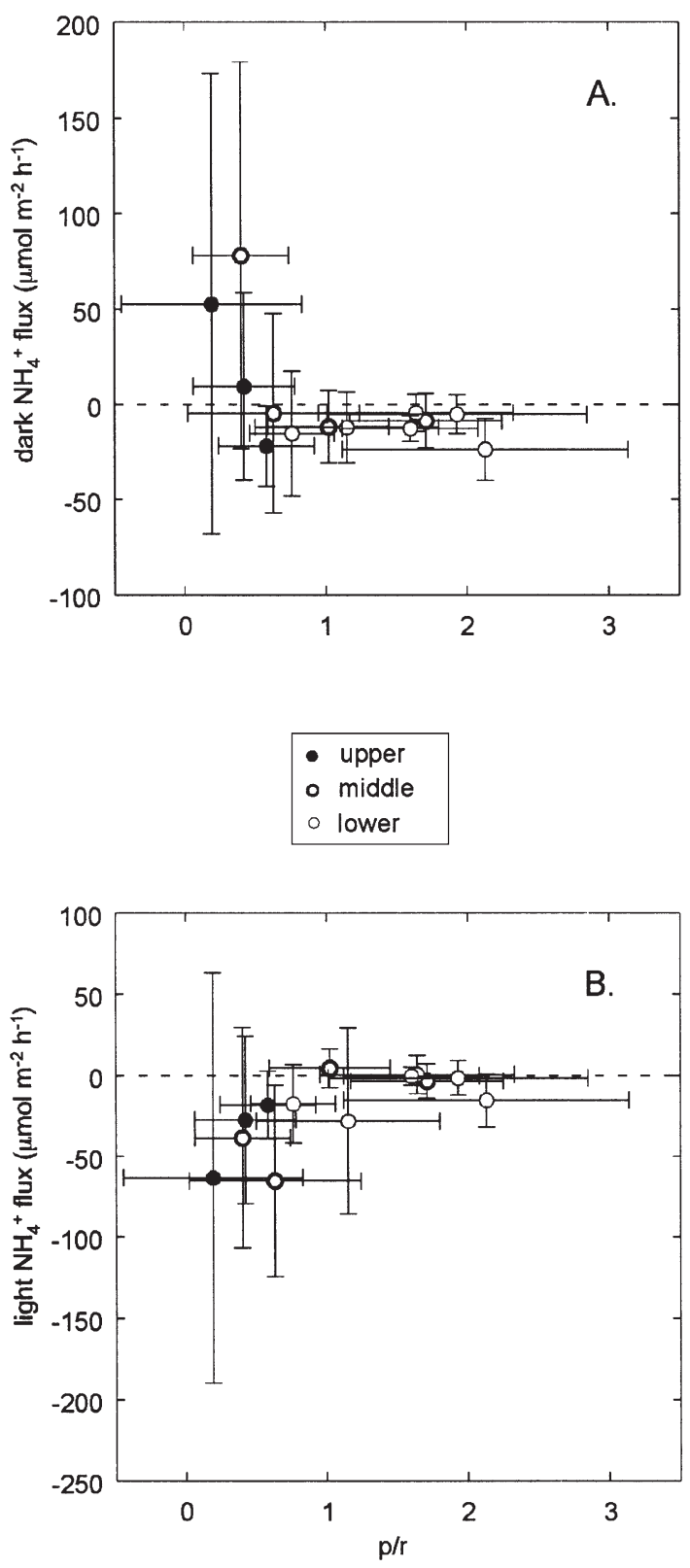

Fig. 5. Fluxes of $\mathrm{NH}_{4}{ }^{+}$during (A) the dark, and (B) the light, plotted as a function of gross productivity/respiration $(p / r)$. Uptakes are greatest at the theoretical peak in competition between heterotrophic and autotrophic microbes, occurring in the zone where both communities are closest to maximum metabolism (i.e. p/r 0.5 to 1). Major effluxes of $\mathrm{NH}_{4}{ }^{+}$were only recorded at $\mathrm{p} / \mathrm{r}<0.5$

\section{Net benthic metabolism: $\mathrm{p} / \mathrm{r}$}

It is evident that nutrient cycling in euphotic sediments of the study estuaries may be influenced by autotrophic assimilation, and that this may lead to competition for $\mathrm{N}$ substrates between autotrophic and heterotrophic communities. For example, competition may occur between BMA and nitrifying bacteria for ammonium substrates (Sundback \& Miles 2000). In addition, heterotrophic bacteria require $\mathrm{N}$ for protein synthesis and incorporation of DIN by active growth of these bacteria may also promote competition and reduce effluxes from sediments (van Duyl et al. 1993, Caraco et al. 1998). In terms of $\mathrm{p} / \mathrm{r}$, the theoretical peak in competition for a limited resource should occur where both metabolic processes are at a maximum, which occurs at a $\mathrm{p} / \mathrm{r}=1$ (i.e. all carbon fixed autotrophically is heterotrophically respired). Benthic respiration rates actually peak at $\mathrm{p} / \mathrm{r}<1$ due to the effects of allochthonous OM inputs such as phytodetritus and leaf litter fall; therefore, in practice the competition maximum will fall in between $\mathrm{p} / \mathrm{r}=0.5$ for sediments where phyto-detritus inputs contribute to heterotrophic activity and $\mathrm{p} / \mathrm{r}=1$ where BMA is the main OM source.

Nutrient fluxes across the sediment-water interface reflect these patterns of metabolism and competition as shown by the relationship between $\mathrm{p} / \mathrm{r}$ and dark $\mathrm{NH}_{4}{ }^{+}$fluxes (Fig. 5). Throughout the entire study, $\mathrm{NH}_{4}{ }^{+}$ effluxes primarily occurred in net heterotrophic sediments (i.e. $\mathrm{p} / \mathrm{r}<1$ ), with the largest effluxes occurring in sediments where $\mathrm{p} / \mathrm{r}$ approached 0 . However, net heterotrophic sediments often displayed reduced effluxes or even uptakes of DIN during the dark, with peak uptakes occurring at a $\mathrm{p} / \mathrm{r} \approx 0.5$ (i.e. the zone of maximum competition). There is a distinct cut-off of $\mathrm{NH}_{4}{ }^{+}$effluxes at a $\mathrm{p} / \mathrm{r}>1$ (Fig. 5A), and fluxes are reduced to close to zero, indicating a complete recycling of DIN and net assimilation of DIN in autotrophic sediments. There is also commonly a distinct binding of the surface sediments with mucus exudates from microalgae (Paterson 1989), which may also form a physical barrier to fluxes.

During the light, there was a similar distinction between net autotrophic and heterotrophic sediments, where benthic fluxes in the net autotrophic sediments remained close to zero (Fig. 5B), while the largest fluxes occurred at $\mathrm{p} / \mathrm{r}<1$. Most of these net heterotrophic sediments displayed a reduction in efflux relative to the dark rates, or a conversion to uptake. Again, the peak in uptakes occurred at $\mathrm{p} / \mathrm{r} \approx 0.5$. This indicates that the light-induced changes in fluxes described above occurred primarily in net heterotrophic sediments with moderate rates of autotrophic productivity. 


\section{Immobilisation in biomass}

The hypothesis of DIN assimilation/immobilisation by autotrophic organisms is supported the positive relationship between porewater $\mathrm{NH}_{4}{ }^{+}$in the surface sediments $(0$ to $-1 \mathrm{~cm})$ and benthic productivity $\left(\mathrm{r}^{2}=\right.$ $0.30, \mathrm{p}=0.05)$. A large proportion of this surface porewater $\mathrm{NH}_{4}{ }^{+}$was present as the freeze-lysable fraction (Fig. 2). The KCl-lysable fraction of $\mathrm{NH}_{4}{ }^{+}$in porewater has been shown to be positively related to bacteria counts in sediment (Aller 1994) and it would seem reasonable to invoke a similar relationship for BMA. However, it is likely that the freeze-lysable $\mathrm{NH}_{4}{ }^{+}$fraction in surficial porewaters represents intra-cell nitrogen due to a combination of microalgae, bacteria, and protozoa. Heterotrophic mineralisation of OM will tend promote the release of cell-bound nitrogen and increase the relative size of the free $\mathrm{NH}_{4}{ }^{+}$porewater pool. This is evident from the increase in $\mathrm{NH}_{4}{ }^{+}$effluxes during the dark when heterotrophic metabolism becomes relatively more important.

Bacterial production, and hence $\mathrm{N}$-assimilation, is stimulated by inputs of labile OM (Haack \& McFeters 1982, van Duyl \& Kop 1994, Cherrier et al. 1996, Pedersen et al. 1999), and through bioturbation and coprophagy by meio and macrofauna (Gerlach 1978, Meyer-Reil \& Faubel 1980, Montagna 1984, Tenore 1988, Miller et al. 1995). High rates of BMA productivity in the middle to lower estuaries result in a relatively steady supply of both dissolved and particulate labile OM (Ferguson et al. 2003) and provide favourable redox conditions for the proliferation of aerobic microbes and grazers. Various workers have demonstrated an inverse relationship between the biomass/ abundance of microbes and meiofauna, suggesting that the turnover of bacterial biomass is rapid in the presence of high grazing pressure (Meyer-Reil \& Faubel 1980, Grant \& Schwinghamer 1987) and that a significant portion of OM taken up by meiofauna is of bacterial origin (Meyer-Reil \& Faubel 1980). It is likely that microbial biomass is kept at a minimum by protozoan and meiofaunal grazing, while further bacterial production is stimulated by bioturbation (Lillebo et al. 1999). The simultaneous grazing and stimulation of new bacterial biomass would therefore tend to promote immobilisation of nitrogen in living biomass and shunt a certain proportion up to metazoan levels of the foodchain. The assimilation efficiency of energy (and nutrients) tends to decrease with increases in organism biomass and trophic level (Valiela 1995); therefore, it can be expected that nitrogen may be recycled from the benthos via macrofaunal excretion. This was evident during the present study where there was a weak positive relationship between $\mathrm{NH}_{4}{ }^{+}$fluxes and the abundance of polychaetes and bivalves in cores $\left(\mathrm{r}^{2}=\right.$
0.17 and 0.12, respectively); however, it is unclear whether this was due directly to excretion or the effects of bio-irrigation.

Production/biomass ratios (P/B) of BMA during the study indicate a rapid turnover of BMA biomass (up to 6 times $\mathrm{d}^{-1}$ ), which may be due to grazing by both infauna and epifauna. This is supported by a positive correlation between $\mathrm{P} / \mathrm{B}$ and macrofaunal biomass $\left(\mathrm{r}^{2}=\right.$ $0.77 ; \mathrm{p}<0.0001)$, indicating that the high turnover of BMA biomass related directly to increases in biomass at higher trophic levels. However, this relationship should be viewed in relation to the various OM supplies to sediments in different parts of the estuary. For example, high macrofaunal biomasses in the middle to upper Brunswick estuary may be primarily a result of large phytodetritus inputs, and high benthic grazing rates may represent top-down controls on BMA biomass in these parts of the estuary. In contrast, the lower estuary benthic foodchains may be more dependent on BMA productivity as shown by a general increase in macrofaunal biomass at a $\mathrm{p} / \mathrm{r}=1$ (Ferguson et al. in press), and thus BMA productivity forms a bottom-up control on infaunal biomass. The exception to this was in the lower Brunswick estuary, where a high P/B did not relate to a higher macrofaunal biomass. This site was exposed to relatively high-energy currents, and shoals were characterised by mega-ripples; therefore, it is likely that BMA biomass was constantly buried or exported, thereby reducing the biomass build-up observed at other lower estuary sites.

A simple budget has been constructed to test the plausibility of DIN immobilisation in biomass by accounting for the net assimilation of DIN into BMA and macrofaunal biomass at each site throughout the study (Table 3). Denitrification has also been included in the budget at sites where it was measured. The budget uses site averages for the entire year and therefore integrates spatial and seasonal variations. Net DIN assimilation by BMA consistently accounted for the bulk of regenerated DIN at the lower estuary sites (73 to $231 \%$; mean $112 \%$ ) with smaller assimilation rates in the middle estuary sites where net autotrophic production was lower ( 21 to $40 \%$; mean $28 \%$ ). Rates of net assimilation by macrofauna were lower than for BMA in the upper and lower estuaries (means 4 and $6 \%$, respectively) and similar to BMA assimilation in the middle estuaries due to the large biomass of bivalves (mean $30 \%$ ). The relative importance of denitrification as a potential sink in the Brunswick estuary was greatest in the middle reaches (mean 117\%) followed by the lower estuary (mean $26 \%$ ) and the upper estuary (mean 5\%).

It is clear from the budget that biomass assimilation, along with measured fluxes, can account for a major proportion of the expected $\mathrm{N}$ regeneration at most sites (Fig. 6). Notable exceptions are the upper estuary sites 
Table 3. A budget accounting for the potential nitrogen sinks due to assimilation by benthic microalgae (BMA) and macrofauna, and denitrification at sites in the Brunswick-Simpsons estuary system and the Sandon estuary. These sinks are also expressed as a percentage of the total dissolved nitrogen pool. All terms are in $\mu \mathrm{mol} \mathrm{N} \mathrm{m} \mathrm{N}^{-2} \mathrm{~d}^{-1}$ and are calculated as the average of all measurements $(n=12)$ at a site over the year. DIN mineralisation $=$ dark hourly $\mathrm{TCO}_{2}$ flux $\times 24 \times 16 / 107$; TDN flux $=$ net daily DIN + DON flux; Dissolved N pool = DIN mineralisation - TDN flux; Net BMA assimilation = net daily $\mathrm{TCO}_{2}$ fixation $\times 16 / 107$; Macrofaunal assimilation $=$ net daily macrofaunal production $\times 10 / 107$. Macrofaunal production was estimated from biomass increase between sample times (data from Ferguson et al. in press)

\begin{tabular}{|c|c|c|c|c|c|c|c|c|c|c|}
\hline \multirow{2}{*}{$\begin{array}{l}\text { Estuary } \\
\text { Brunswick }\end{array}$} & \multirow{2}{*}{$\begin{array}{c}\text { Site } \\
\text { RW }\end{array}$} & \multirow{2}{*}{$\begin{array}{c}\begin{array}{c}\text { DIN } \\
\text { mineralisation }\end{array} \\
8091\end{array}$} & \multirow{2}{*}{$\begin{array}{r}\begin{array}{l}\text { TDN } \\
\text { flux }\end{array} \\
316\end{array}$} & \multirow{2}{*}{$\begin{array}{c}\begin{array}{c}\text { Dissolved } \\
\text { N pool }\end{array} \\
7775\end{array}$} & \multicolumn{2}{|c|}{$\begin{array}{c}\text { Net BMA } \\
\text { assimilation }\end{array}$} & \multicolumn{2}{|c|}{$\begin{array}{l}\text { Macrofaunal } \\
\text { assimilation }\end{array}$} & \multicolumn{2}{|c|}{$\mathrm{N}_{2}$ flux } \\
\hline & & & & & 0 & $0 \%$ & 726 & $9 \%$ & 386 & $5 \%$ \\
\hline & $\mathrm{SG}$ & 3483 & -1602 & 5085 & 1072 & $21 \%$ & 1960 & $39 \%$ & 5947 & $117 \%$ \\
\hline & OY & 5595 & 564 & 5031 & 1128 & $22 \%$ & 1803 & $36 \%$ & - & - \\
\hline & $\mathrm{BR}$ & 2536 & -891 & 3427 & 3687 & $108 \%$ & 80 & $2 \%$ & 888 & $26 \%$ \\
\hline \multirow[t]{3}{*}{ Simpsons } & SU & 3745 & -832 & 4577 & 0 & $0 \%$ & 35 & $1 \%$ & - & - \\
\hline & STP & 2014 & -948 & 2962 & 779 & $26 \%$ & 523 & $18 \%$ & - & - \\
\hline & SL & 3362 & -807 & 4170 & 3186 & $76 \%$ & 523 & $13 \%$ & - & - \\
\hline \multirow[t]{6}{*}{ Sandon } & EN & 962 & -831 & 1793 & 0 & $0 \%$ & 39 & $2 \%$ & - & - \\
\hline & RHY & 4263 & -422 & 4685 & 1915 & $41 \%$ & 1202 & $26 \%$ & - & - \\
\hline & $\mathrm{CON}$ & 2477 & -618 & 3095 & 2500 & $81 \%$ & 216 & $7 \%$ & - & - \\
\hline & OSP & 5023 & -105 & 5128 & 5184 & $101 \%$ & 171 & $3 \%$ & - & - \\
\hline & SUB & 2723 & -263 & 2986 & 2171 & $73 \%$ & 109 & $4 \%$ & - & - \\
\hline & $\mathrm{WF}$ & 1909 & -337 & 2246 & 5243 & $233 \%$ & 138 & $6 \%$ & - & - \\
\hline
\end{tabular}

in all 3 systems where there are still large amounts of unaccounted for DIN. This is likely to be due to the breakdown of relatively larger proportions of high C:N OM such as leaf litter at these sites (Ferguson et al. 2003). Since the expected $N$ regeneration term in the budget has been calculated assuming Redfield $\mathrm{C}: \mathrm{N}$ for $\mathrm{OM}$, the expected rates at the upper estuary sites will be overestimated. Other exceptions were observed at

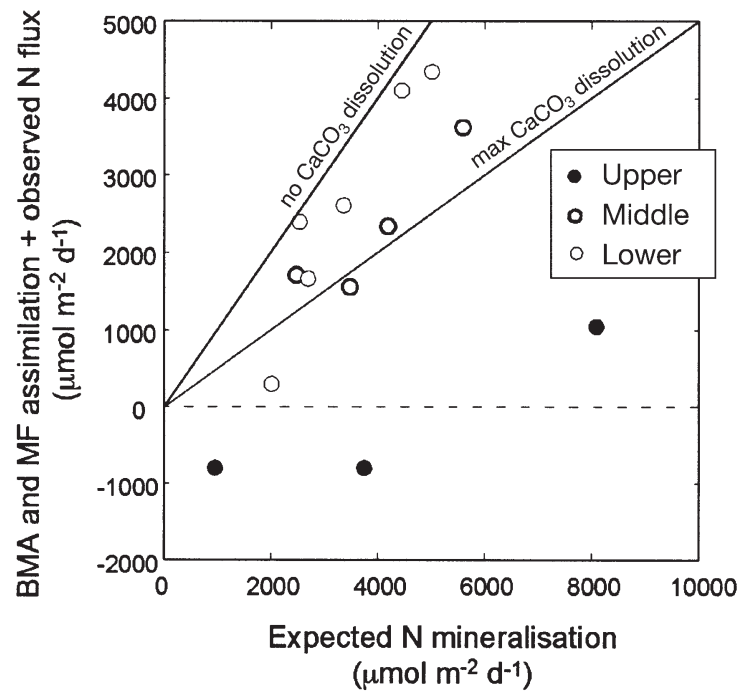

Fig. 6. Potential assimilation of nitrogen into biomass of benthic microalgae (BMA) and macrofauna (MF) plus observed $\mathrm{N}$ fluxes compared with expected theoretical $\mathrm{N}$ mineralisation calculated from $\mathrm{TCO}_{2}$ respiration assuming the breakdown of Redfield algae. Denitrification has not been included as data are not available for all sites
Sites STP and SG, where assimilation did not account for mineralised N. Alkalinity fluxes and $\mathrm{TCO}_{2}: \mathrm{O}_{2}$ flux ratios both indicated potentially high rates of nitrification at these sites (Ferguson et al. 2003), indicating that coupled nitrification-denitrification $\left(D_{\mathrm{n}}\right)$ may account for the missing $\mathrm{N}$. This is further supported by the high denitrification rates recorded at Site SG during the wet season. At Site $\mathrm{WF}$, assimilation rates were much higher than expected $\mathrm{N}$ mineralisation. This may be due to an underestimation of $\mathrm{N}$ mineralisation due to a depressed $\mathrm{TCO}_{2}$ flux in the dark. Extremely high benthic productivity at this site (up to $8000 \mu \mathrm{mol} \mathrm{O}_{2} \mathrm{~m}^{-2}$ $\mathrm{h}^{-1}$ ) often resulted in $\mathrm{TCO}_{2}$ uptakes continuing into the dark period due to $\mathrm{TCO}_{2}$ limitation in the sediments; thus, respiration (and hence $\mathrm{N}$ mineralisation) rates were underestimated. Using $\mathrm{O}_{2}$ respiration rates for this site yields $\mathrm{N}$ mineralisation rates within the expected range (Fig. 6).

Immobilisation in biomass represents a quasiequilibrium state holding for short periods (hours to seasons) and does not hold over longer periods (i.e. years), since benthic biomass is not observed to continually increase. The shift between net immobilisation and release may occur over the diurnal cycle, thereby reflecting the shifting balance between autotrophic and heterotrophic microbes during the light and dark periods (e.g. $\mathrm{NH}_{4}{ }^{+}$fluxes for Brunswick estuary during the spring dry season). However, despite diurnal fluctuations, net $24 \mathrm{~h}$ fluxes were commonly uptakes, most likely due to increases in the biomass and/or P/B ratios of microbial and metazoan populations over seasonal time scales. The accumulation of BMA biomass in 
autotrophic sediments is controlled by a combination of production, grazing by infauna and epifauna as well as scouring or resuspension. The biomass of macrofauna was significantly higher in the middle to upper Brunswick estuary (Ferguson et al. in press), suggesting controls by resource supply in these estuaries. Long-term laboratory incubations of sediment cores from the Brunswick estuary showed that macrofaunal populations were capable of rapidly denuding BMA biomass (within days) in the absence of a constant rain of phytodetritus from the water column. However, the ultimate control on biomass accumulation may be exerted by the scouring effects of high flow events, which lead to distinct biomass minima following the wet season (Corfield 2000).

\section{DON fluxes - interactions with metabolism}

There were distinct differences in DON fluxes between the upper and middle estuary sites, and the lower estuaries that appeared to be influenced by net metabolism (Fig. 7). In general, DON fluxes followed similar patterns to DIN fluxes in net heterotrophic sediments with DON effluxes increasing as $\mathrm{p} / \mathrm{r}$ approached zero, and peak DON uptakes at around a $\mathrm{p} / \mathrm{r}$ of 0.5 . Uptake of DON may be due to heterotrophic utilisation of dissolved organic substrates in areas of maximal competition (Rondell et al. 2000); however, it is also possible that DON uptake is due to the autotrophic assimilation of urea (Bronk et al. 1998). There was a distinction between wet season fluxes (effluxes) and dry season fluxes (uptakes), suggesting that DON

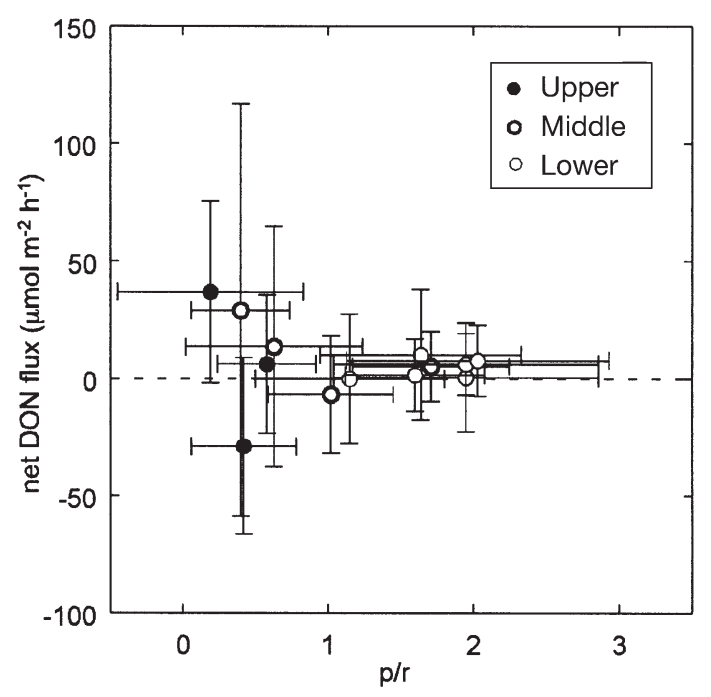

Fig. 7. Dissolved organic nitrogen (DON) fluxes versus gross net benthic metabolism (productivity/respiration, p/r) fluxes may also be influenced by the rate of OM supply to the sediments. During the wet season, when OM supply and benthic respiration rates were generally greatest, there were large releases of DON in the upper to middle Brunswick estuary. High rates of OM supply to the sediments resulted in a predominance of microbial over metazoan activity, with the hydrolysis of OM exceeding the rate of DON consumption by ammonification, thereby resulting in DON effluxes. This would indicate nutrient-replete conditions in the benthos. In contrast, during the dry season, when the OM supply rate is smaller and more stable, DON in the water column may become an important energy/nutrient source for heterotrophic microbes.

There was a progression from uptakes at p/r 0.5 to 1, through to effluxes at $\mathrm{p} / \mathrm{r}>1$ (Fig. 7). The progression towards DON effluxes with increasing autotrophy suggests a predominance of autotrophic release (Glibert \& Bronk 1994), which is further supported by the enhanced DON efflux during the light. Sediments in the middle Sandon estuary tended to be much more autotrophic than comparable reaches of the Brunswick or Simpsons estuaries and as such displayed similar DON flux behaviour to the lower estuary sites. Due to the relatively more stable nature of water quality and OM supply throughout the year in the lower estuarine environment, there were no real seasonal trends or distinctions between estuaries in the relationship between $\mathrm{p} / \mathrm{r}$ and DON fluxes.

\section{Comparisons with other systems}

A comparison of the estuaries studied with other sub-tropical, warm temperate and cool temperate estuaries has been made with regards to $\mathrm{O}_{2}$ and $\mathrm{NH}_{4}{ }^{+}$ fluxes in Fig. 8. The departure of $\mathrm{O}_{2}: \mathrm{NH}_{4}{ }^{+}$flux ratios from the expected Redfield stoichiometry for algal material has commonly been used to broadly assess the relative importance of various benthic metabolic processes: lower-than-expected indicating the presence of significant rates of anaerobic respiration such as sulphate reduction, and higher-than-expected indicating significant rates of nitrification (Banta et al. 1995, Cowan et al. 1996, Twilley et al. 1999). Fig. 8 clearly shows that $\mathrm{O}_{2}: \mathrm{NH}_{4}{ }^{+}$flux ratios for the BrunswickSimpsons and Sandon estuaries, along with other subtropical or warm temperate systems, plot well above the expected $\mathrm{O}_{2}: \mathrm{N}$ ratio of 6.625 around an average of 35 . In contrast, the cool temperate systems plot close to, or below, Redfield, with some large excesses in $\mathrm{NH}_{4}{ }^{+}$ fluxes relative to $\mathrm{O}_{2}$, indicating the presence of significant rates of sulphate reduction (Cowan et al. 1996). The range for the upper Brunswick estuary also crosses into this region due to the effects of the sum- 


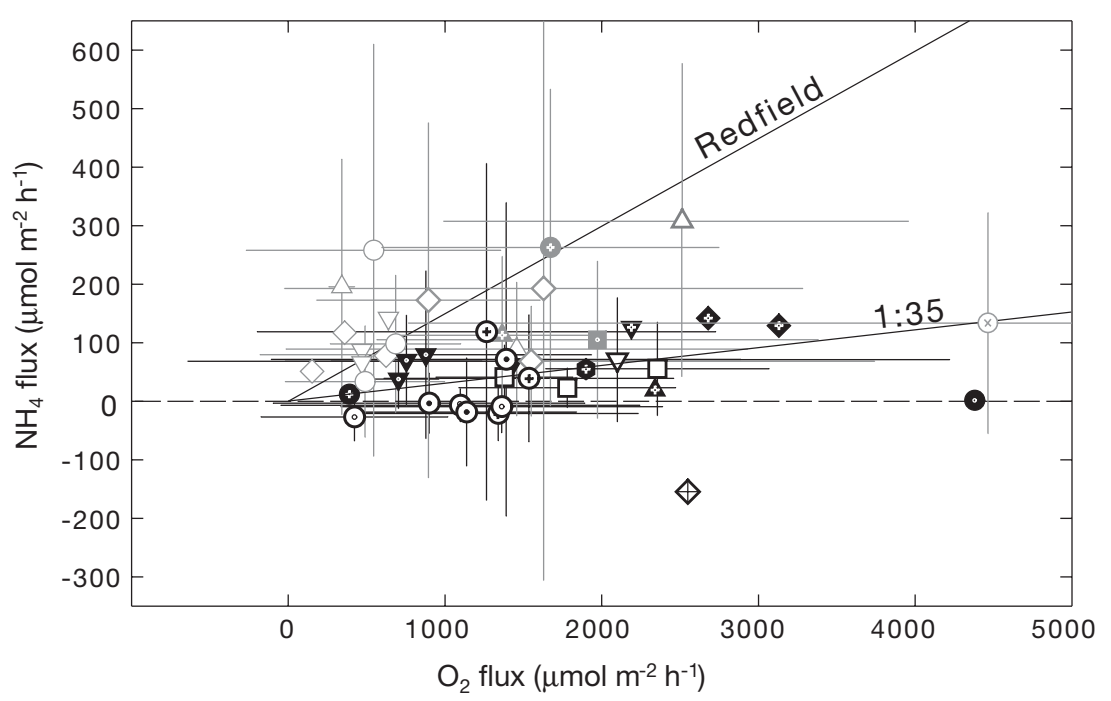

Fig. 8. A comparison of $\mathrm{O}_{2}$ respiration rates and $\mathrm{NH}_{4}{ }^{+}$fluxes for the study systems and other sub-tropical and temperate systems in Australia and the northern hemisphere. Points represent the mean and standard deviation of the reported range for each system. Included is the relationship expected for the aerobic mineralisation of Redfield algae (16:106). The sub-tropical systems plot well below this ratio around an average of (1:35), indicating that a significant proportion of recycled $\mathrm{N}$ is either denitrified or immobilised in biomass, or alternatively that Redfield ratios are inappropriate for assessing metabolism in these systems. Most reaches of the Brunswick-Simpsons and Sandon estuaries plot close to zero due to the impacts of benthic productivity on benthic $\mathrm{N}$ recycling (the 3 points plotting higher represent nutrient-enriched reaches of the Brunswick-Simpsons system)
Australian sub-tropical + warm temperate

\begin{tabular}{|c|c|c|}
\hline \multicolumn{3}{|c|}{ Brunswick-Simpsons and Sandon estuaries } \\
\hline$\oplus$ & upper & This study \\
\hline ค & middle & This study \\
\hline & lower & This study \\
\hline & Lake Macquarie & Eyre \& Ferguson (2002) \\
\hline & Sydney Lagoons & Eyre \& Ferguson (2002) \\
\hline & Moreton Bay & Dennison \& Abal (1999) \\
\hline \multicolumn{3}{|c|}{ Other sub-tropical + warm temperate } \\
\hline & Ochlockonee Bay & Seitzinger (1987) \\
\hline & Mobile Bay & Cowan et al. (1996) \\
\hline & Mississippi River Bight & Twilley \& McKee (1996) \\
\hline & Fourleague Bay & $\begin{array}{l}\text { Miller-Way et al. (1994); } \\
\text { Twilley et al. (1999) }\end{array}$ \\
\hline & Guadalupe estuary & Twilley et al. (1999) \\
\hline & Trinity-San Jacinto estuary & $\begin{array}{l}\text { Zimmerman \& } \\
\text { Benner (1994) }\end{array}$ \\
\hline & Laguna Madre-Upper & Twilley et al. (1999) \\
\hline & Nueces estuary & Twilley et al. (1999) \\
\hline
\end{tabular}

Australian temperate

$\triangle$ Port Phillip Bay

Berelson et al. (1998)

Other temperate

$$
\begin{aligned}
& \text { Chesapeake Bay } \\
& \text { Parkes River estuary } \\
& \text { Neuse River estuary } \\
& \text { Tomales Bay } \\
& \text { Patuxent River } \\
& \text { Neuse River } \\
& \text { San Francisco Bay } \\
& \text { South River estuary }
\end{aligned}
$$

Cowan \& Boynton (1996) Hopkinson et al. (1999) Rizzo \& Christian (1996) Dollar et al. (1991) Fischer et al. (1982) Fischer et al. (1982) Hammond et al. (1985) Fischer et al. (1982) mer wet season run, where $\mathrm{TCO}_{2}: \mathrm{O}_{2}$ fluxes indicated that sulphate reduction exceeded oxidation by up to 5fold (Ferguson et al. 2003).

The question remains whether the shortfall in $\mathrm{NH}_{4}{ }^{+}$ regeneration relative to $\mathrm{O}_{2}$ consumption displayed in the sub-tropical systems is due to coupled nitrificationdenitrification or other processes such as sulphide oxidation, assimilation into biomass by BMA and bacteria, or alternatively the mineralisation of OM with a higher $\mathrm{C}: \mathrm{N}$ ratio than microalgae. It has been demonstrated by this study that BMA may exert significant direct and indirect influences on both $\mathrm{O}_{2}$ and $\mathrm{N}$ fluxes according to all the above-mentioned processes, thereby altering the flux ratios. Furthermore, there is evidence that BMA and phyto-detritus both make significant contributions to the benthic OM pool in different parts of these estuaries, suggesting that Redfield ratios may be appropriate (Ferguson et al. 2003). However, in at least some of the other sub-tropical systems included in the comparison, BMA was thought to be only a minor player (Cowan et al. 1996), and nitrification was invoked as the major sink of $\mathrm{NH}_{4}{ }^{+}$. This was supported by $\mathrm{NO}_{3}{ }^{-}$flux behaviour, which showed an inverse relationship to $\mathrm{NH}_{4}{ }^{+}$(Twilley et al. 1999). No such relationships were observed in the current study, with the sediments appearing to be $\mathrm{NO}_{3}{ }^{-}$-limited and evidence of a potentially large assimilatory pathway for $\mathrm{NH}_{4}{ }^{+}$. The occurrence of high rates of benthic pro- ductivity in the lower to middle Brunswick-Simpsons and Sandon estuaries appears to increase $\mathrm{O}_{2}: \mathrm{NH}_{4}{ }^{+}$flux ratios above the general trend for the other subtropical systems. Only in the nutrient-enriched upper and middle Brunswick and upper Simpsons estuary where benthic productivity was relatively suppressed by light attenuation from phytoplankton blooms do flux ratios appear similar.

\section{Synthesis - a conceptual model of nutrient cycling in shallow sub-tropical estuaries}

Nitrogen cycling in the euphotic sediments of these shallow estuaries is influenced by a complex set of interactions between autotrophic and heterotrophic organisms over the full $24 \mathrm{~h}$ diurnal cycle (Fig. 9). Accordingly, the net $24 \mathrm{~h}$ metabolism, or $\mathrm{p} / \mathrm{r}$ ratio, is a useful concept in understanding the net effects of metabolic processes on nutrient cycling since it classifies benthic communities on a scale from entirely heterotrophic to net autotrophic. Nutrients are cycled between dissolved and particulate, inorganic and organic and gaseous (nitrogen) forms; however, due to the high primary and secondary productivity, nutrients are usually retained in the sediments with increasing autotrophy. The major effluxes in net autotrophic sediments are dissolved organic nutrients. It is hypothesized that com- 


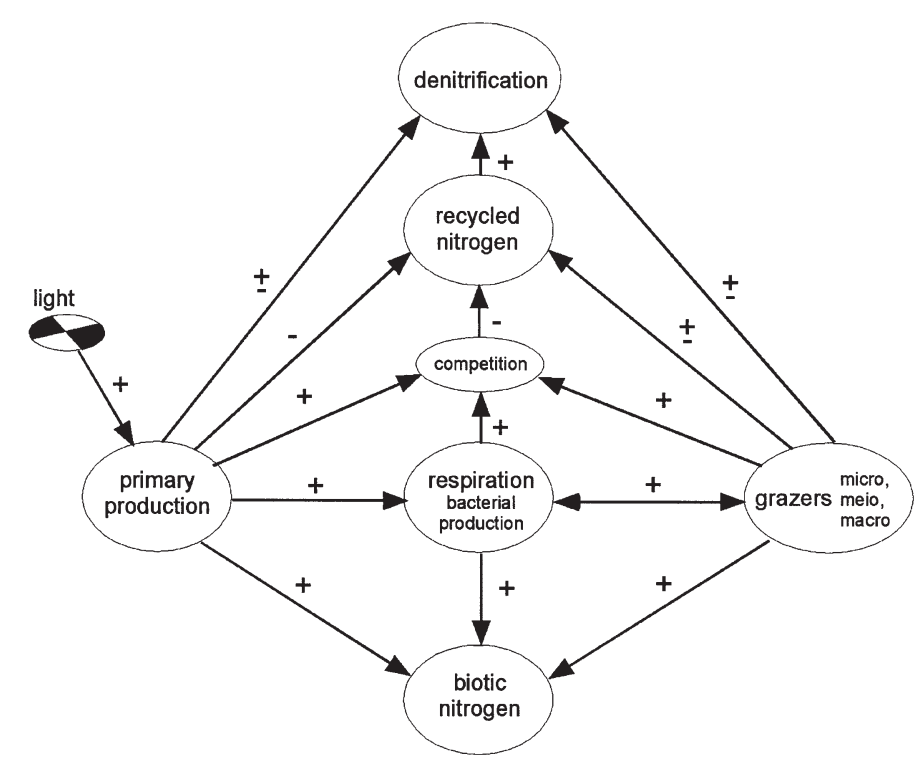

Fig. 9. Relationships between primary factors influencing benthic nitrogen recycling in euphotic sediments of shallow, sub-tropical Australian estuaries. In this model, light is the primary forcing factor leading to benthic productivity by benthic microalgae (BMA). An increase in labile OM supply due to BMA stimulates bacterial production, which in turn stimulates higher trophic levels. All of these trophic levels promote competition for inorganic $\mathrm{N}$ substrates, thereby forming a negative feedback to the recycled $\mathrm{N}$ pathway. In this way, benthic productivity tends to favour immobilisation of $\mathrm{N}$ in biomass over regeneration to the water column and even denitrification

petition for nutrient substrates (especially nitrogen) between autotrophic and heterotrophic organisms is a major control on nutrient cycling, potentially limiting processes such as coupled nitrification-denitrification. A small percentage of net heterotrophic sediments recycle inorganic nutrients back to the water column during periods of excessive OM loading such as during the growth phase of large phytoplankton blooms. Denitrification typically accounts for a relatively small fraction of nitrogen metabolism in highly autotrophic sediments, implicating immobilisation in biomass and flow up the food chain as a potentially major pathway of nitrogen removal in the middle to lower reaches of these estuaries.

Acknowledgements. This study was funded by an Australian Postgraduate Award.

\section{LITERATURE CITED}

Aller RC (1986) The effects of macrobenthos on chemical properties of marine sediment and overlying water. In: McCall PL, Tevesz JS (eds) Animal sediment relations: the biogenic alteration of sediments. Plenum Press, New York, p 53-102

Aller RC (1988) Benthic fauna and biogeochemical processes in marine sediments: the role of burrow structures. In: Blackburn TH, Sørensen J (eds) Nitrogen cycling in coastal marine environments. John Wiley \& Sons, Chichester, p 301-338

Aller RC (1994) Bioturbation and remineralization of sedimentary organic matter: effects of redox oscillation. Chem Geol 114:331-345

Almgren T, Dryssen D, Fonselius S (1983) Determination of alkalinity and total carbonate. In: Grasshoff $\mathrm{K}$, Ehrnhardt M, Kremling K (eds) Methods of seawater analysis. Verlag Chemie, Weinheim, p 99-123

Andersen TK, Jensen MH, Sørensen J (1984) Diurnal variation of nitrogen cycling in coastal, marine sediments. Mar Biol 83:171-176

Banta GT, Giblin AE, Tucker J, Hobbie JE (1994) Comparison of two indirect methods of estimating denitrification rates for Buzzards Bay, Massachusetts. In: Dyer KR, Orth RJ (eds) Changes in fluxes in estuaries: implications from science to management. Olsen \& Olsen, Fredensborg, p 203-209

Banta GT, Giblin AE, Hobbie JE, Tucker J (1995) Benthic respiration and nitrogen release in Buzzards Bay, Massachusetts. J Mar Res 53:107-135

Barnes J, Owens NJP (1998) Denitrification and nitrous oxide concentrations in the Humber estuary, UK, and adjacent coastal zones. Mar Pollut Bull 37(3-7):247-260

Berelson W, Heggie D, Longmore A, Kilgore T, Nicholson G, Skyring G (1998) Benthic nutrient recycling in Port Phillip Bay, Australia. Estuar Coast Shelf Sci 46:917-934

Bird FL, Ford PW, Hancock GJ (1999) Effect of burrowing macrobenthos on the flux of dissolved substances across the water-sediment interface. Mar Freshw Res 50:523-532

Blackburn TH (1988) Benthic mineralization and bacterial production. In: Blackburn TH, Sørensen J (eds) Nitrogen cycling in coastal marine environments. John Wiley \& Sons, Chichester, p 175-206

Blackburn TH (1990) Denitrification model for marine sediment. In: Revsbech NP, Sørensen J (eds) Denitrification in soil and sediment. Plenum Press, New York, p 323-337

Blackburn TH, Henriksen K (1983) Nitrogen cycling in different types of sediments from Danish waters. Limnol Oceanogr 28:477-493

Blackburn TH, Hall POJ, Hulth S, Landen A (1996) Organic-N loss by efflux and burial associated with a low efflux of inorganic $\mathrm{N}$ and with nitrate assimilation in Arctic sediments (Svalbard, Norway). Mar Ecol Prog Ser 141:283-293

Bonin P, Omnes P, Chalamet A (1998) Simultaneous occurrence of denitrification and nitrate ammonification in sediments of the French Mediterranean Coast. Hydrobiologia 389:169-182

Boynton WR, Kemp M (1985) Nutrient regeneration and oxygen consumption by sediments along an estuarine salinity gradient. Mar Ecol Prog Ser 23:45-55

Bronk DA, Glibert PM, Malone TC, Banahan S, Sahlsten E (1998) Inorganic and organic nitrogen cycling in Cheaspeake Bay: autotrophic versus heterotrophic processes and relationships to carbon flux. Aquat Microb Ecol 15:177-189

Burdige DJ, Zheng S (1998) The biochemical cycling of dissolved organic nitrogen in estuarine sediments. Limnol Oceanogr 43(8):1796-1813

Cadee GC, Hegeman J (1977) Distribution of primary production of the benthic microflora and accumulation of organic matter on a tidal flat area, Balgzand, Dutch Wadden Sea. Neth J Sea Res 11(1):24-41

Caraco NF, Lampman G, Cole JJ, Limburg KE, Pace ML, Fischer D (1998) Microbial assimilation of DIN in a nitrogen rich estuary: implications for food quality and isotope studies. Mar Ecol Prog Ser 167:59-71 
Cherrier J, Bauer JE, Druffel ERM (1996) Utilisation and turnover of labile dissolved organic matter by bacterial heterotrophs in eastern North Pacific surface waters. Mar Ecol Prog Ser 139:267-279

Christensen PB, Nielsen LP, Revsbech NP, Sørensen J (1989) Microzonation of denitrification activity in stream sediments as studied with a combined oxygen and nitrous oxide microsensor. Appl Environ Microb 55(5):1234-1241

Christensen PB, Nielsen LP, Sørensen J, Revsbech NP (1990) Denitrification in nitrate-rich streams: diurnal and seasonal variation related to benthic oxygen metabolism. Limnol Oceanogr 35(3):640-651

Colijn F, de Jonge VN (1984) Primary production of microphytobenthos in the Ems-Dollard estuary. Mar Ecol Prog Ser 14:185-196

Corfield J (2000). Macrobenthic community dynamics in the Richmond River estuary, northern New South Wales, Australia. Environmental Science and Management, Southern Cross University, Lismore

Cowan JLW, Boynton WR (1996) Sediment-water oxygen and nutrient exchanges along the longitudinal axis of Chesapeake Bay: seasonal patterns, controlling factors and ecological significance. Estuaries 19(3):562-580

Cowan JLW, Pennock JR, Boynton WR (1996) Seasonal and interannual patterns of sediment-water nutrient and oxygen fluxes in Mobile Bay, Alabama (USA): regulating factors and ecological significance. Mar Ecol Prog Ser 141:229-245

Davies JM (1975) Energy flow through the benthos in a Scottish sea loch. Mar Biol 31:353-362

Dennison WC, Abal EG (1999) Moreton Bay study: a scientific basis for the healthy waterways campaign. South East Queensland Regional water Quality Management Strategy, Brisbane

Dollar SJ, Smith SV, Vink SM, Obrebski S, Hollibaugh JT (1991) Annual cycle of benthic nutrient fluxes in Tomales Bay, California, and contribution of the benthos to total ecosystem metabolism. Mar Ecol Prog Ser 79:115-125

Eyre BD (2000) Regional evaluation of nutrient transformation and phytoplankton growth innine river-dominated sub-tropical east Australian estuaries. Mar Ecol Prog Ser 205:61-83

Eyre BD, Ferguson AJP (2002) Comparison of carbon production and decomposition, benthic nutrient fluxes and denitrification in seagrass, phytoplankton, benthic microalgaeand macroalgae-dominated warm-temperate Australian lagoons. Mar Ecol Prog Ser 229: 43-59

Falkowski PG, Raven JA (1997) Aquatic photosynthesis. Blackwell Science, Malden, MA

Ferguson AJP, Eyre BD, Gay JM (2003) Organic matter and benthic metabolism in euphotic sediments along shallow sub-tropical estuaries, northern New South Wales, Australia. Aquat Microb Ecol 33:137-154

Ferguson AJP, Eyre BD, Gay JM (2004) Nutrient cycling in the sub-tropical Brunswick estuary, Australia. Estuaries 27(1):1-17

Ferguson AJP, Gay JM, Eyre BD, Corfield J (in press) The effects of nutrient enrichment on benthic processes in shallow sub-tropical estuaries - indicators of eutrophication. Mar Ecol Prog Ser

Fisher TR, Carlson PR, Barber RT (1982) Carbon and nitrogen primary productivity in three North Carolina estuaries. Estuar Coast Shelf Sci 15:621-644

Gerlach SA (1978) Food-chain relationships in subtidal silty sand marine sediments and role of meiofauna in stimulating bacterial productivity. Oecologia 33:55-69

Glibert PM (1993) The interdependence of uptake and release of $\mathrm{NH}_{4}{ }^{+}$and organic nitrogen. Mar Microb Food Webs 7(1):53-67
Glibert PM, Bronk DA (1994) Release of dissolved organic nitrogen by marine diazotrophic cyanobacteria, Trichodesmium spp. Appl Environ Microbiol 60(11):3996-4000

Grant J, Schwinghamer P (1987) Size partitioning of microbial and meiobenthic biomass and respiration on Brown's Bank, south-west Nova Scotia. Estuar Coast Shelf Sci 25: 647-661

Haack TK, McFeters GA (1982) Nutritional relationships among microorganisms in an epilithic biofilm community. Microb Ecol 8:115-126

Hammond D, Fuller C, Harmon D, Hartman B and 6 others (1985) Benthic fluxes in San Francisco Bay. Hydrobiologia 129:69-90

Hammond DE, Giordani P, Berelson WM, Poletti R (1999) Diagenesis of carbon and nutrients and benthic exchange in sediments of the Northern Adriatic Sea. Mar Chem 66: $53-79$

Hopkinson CS, Giblin AE, Tucker J, Garrit RH (1999) Benthic metabolism and nutrient cycling along an estuarine salinity gradient. Estuaries 22(4):863-881

Hydes DJ, Kelly-Gerreyn BA, Le Gall AC, Proctor R (1999) The balance of supply of nutrients and demands of biogical production and denitrification in a temperate latitude shelf sea-a treatment of the southern North Sea as an extended estuary. Mar Chem 68: 117-131

Jensen MH, Lomstein E, Sørensen (1990) Benthic $\mathrm{NH}_{4}{ }^{+}$and $\mathrm{NO}_{3}{ }^{-}$flux following sedimentation of a spring phytoplankton bloom in Aarhus Bight, Denmark. Mar Ecol Prog Ser 61:155-162

Jørgensen BB (1996) Case study-Aarhus Bay. In: Jørgensen BB, Richardson K (eds) Eutrophication in coastal marine ecosystems. American Geophysical Union, Washington, p 137-154

Kana TM, Darkangelo C, Hunt MD, Oldam JB, Bennett GE, Cornwell JC (1994) Membrane inlet mass spectrometer for rapid high-precision determination of $\mathrm{N}_{2}, \mathrm{O}_{2}$, and $\mathrm{Ar}$ in environmental samples. Analyt Chem 66:4166-4170

Keil RG, Kirchman DL (1991) Contribution of dissolved free amino acids and ammonium to the nitrogen requirements of heterotrophic bacterioplankton. Mar Ecol Prog Ser 73:1-10

Kemp WM, Sampou P, Caffrey J, Mayer M (1990) Ammonium recycling versus denitrification in Cheaspeake Bay sediments. Limnol Oceanogr 35(7):1545-1563

Kerr G, Corfield J (1998) Association between the ghost shrimp Trypaea autraliensis Dana 1852 (Crustacea: Decapoda) and a small deposit-feeding bivalve Mysella vitrea Laserson 1956 (Mollusca: Leptonidae). Mar Freshw Res 49:801-806

King D, Nedwell DB (1987) The adaption of nitrate reducing bacterial communities in estuarine sediments in response to overlying nitrate load. FEMS Microbiol Ecol 45:15-26

Kirchman DL, Hodson RE (1986) Metabolic regulation of amino acid uptake in marine waters. Limnol Oceanogr 31(2):339-350

Lachat (1994) International methods list for the QuikChem Automated Ion Analyzer. Lachat Instruments, Milwaukee, WI

Lillebo AI, Flindt MR, Pardal MA, Marques JC (1999) The effect of macrofauna, meiofauna and microfauna on the degradation of Spartina maritima detritus from a salt marsh area. Acta Oecol 20(4):249-258

Lipschultz F, Wofsy SC, Fox LE (1986) Nitrogen metabolism of the eutrophic Delaware River estuary. Limnol Oceanogr 31(4):701-716

Meyer-Reil LA, Faubel A (1980) Uptake of organic matter by meiofauna organisms and interrelationships with bacteria. Mar Ecol Prog Ser 3:251-256

Miller CA, Penry DL, Glibert PM (1995) The impact of trophic 
interactions on rates of nitrogen regeration and grazing in Chesapeake Bay. Limnol Oceanogr 40(5):1005-1011

Miller-Way T, Boland GS, Rowe GT, Twilley RR (1994) Sediment oxygen consumption and benthic nutrient fluxes on the Louisiana continental shelf: a methodological comparison. Estuaries 17(4):809-815

Montagna PA (1984) In situ measurement of meiobenthic grazing rates on sediment bacteria and edaphic diatoms. Mar Ecol Prog Ser 18:119-130

Mortimer RJG, Davey JT, Krom MD, Watson PG, Frickers PE, Clifton RJ (1999) The effect of macrofauna on porewater profiles and nutrient fluxes in the intertidal zone of the Humber estuary. Estuar Coast Shelf Sci 48:683-699

Newell RC, Lucas MI, Linley EAS (1981) Rate of degradation and efficiency of conversion of phytoplankton debris by marine micro-organisms. Mar Ecol Prog Ser 6:123-136

Nixon S (1981) Remineralization and nutrient cycling in coastal marine ecosystems. In: Neilson BJ, Cronin LE (eds) Estuaries and nutrients. Humana, Totowa, NJ, p 111-138

Nowicki B (1994) The effect of temperature, oxygen, salinity, and nutrient enrichment on estuarine denitrification rates measured with a modified nitrogen gas flux technique. Estuar Coast Shelf Sci 38:137-156

O'Donohue MJ, Glibert PM, Dennison WC (2000) Utilisation of nitrogen and carbon by phytoplankton in Moreton Bay, Australia. Mar Freshw Res 51:703-712

Ogilvie B, Nedwell DB, Harrison RM, Robinson A, Sage A (1997) High nitrate, muddy estuaries as nitrogen sinks: the nitrogen budget of the River Colne estuary (United Kingdom). Mar Ecol Prog Ser 150:217-228

Omnes P, Slawyk G, Garcia N, Bonin P (1996) Evidence of denitrification and nitrate ammonification in the River Rhone plume (northhwestern Mediterranean Sea). Mar Ecol Prog Ser 141:275-281

Overnell J, Edwards A, Grantham BE, Harvey SM, Jones KJ, Leftley JW, Smallman DJ (1995) Sediment-water column coupling and the fate of the spring phytoplankton bloom in Loch Linnhe, a Scottish fjordic sea-loch: sediment processes and sediment-water fluxes. Estuar Coast Shelf Sci 41:1-19

Paterson DM (1989) Short-term changes in the erodibility of intertidal cohesive sediments related to the migratory behavior of epipelic diatoms. Limnol Oceanogr 34(1):223-234

Pedersen AGU, Bernsten J, Lomstein BA (1999) The effect of eelgrass decomposition on sediment carbon and nitrogen cycling: a controlled laboratory experiment. Limnol Oceanogr 44(8):1978-1992

Reay WG, Gallagher DL, Simmons GM (1995) Sedimentwater column oxygen and nutrient fluxes in nearshore environments of the lower Delmarva Peninsula, USA. Mar Ecol Prog Ser 118:215-227

Revsbech NP, Sørensen J, Blackburn TH, Lomholt JP (1980) Distribution of oxygen in marine sediments measured with microelectrodes. Limnol Oceanogr 25(3):403-411

Revsbech NP, Jørgensen BB, Brix O (1981) Primary production of microalgae in sediments measured by oxygen profile, $\mathrm{H}^{14} \mathrm{CO}_{3}^{-}$fixation, and oxygen exchange methods. Limnol Oceanogr 24(4):717-730

Rivera-Monroy VH, Twilley RR (1996) The relative role of denitrification and immobilization in the fate of inorganic nitrogen in mangrove sediments (Terminos Lagoon, Mexico). Limnol Oceanogr 41(2):284-296

Rivera-Monroy VH, Twilley RR, Boustany RG, Day JW, VeraHerrera F, Ramirez MDC (1995) Direct denitrification in mangrove sediments in Terminos Lagoon, Mexico. Mar Ecol Prog Ser 126:97-109

Rizzo WM, Christian RR (1996) Significance of subtidal sediments to heterotrophically-mediated oxygen and nutrient dynamics in a temperate estuary. Estuaries 19(2B):
$475-487$

Rizzo WM, Wetzel RL (1985) Intertidal and shoal benthic community metabolism in a temperate estuary: studies of spatial and temporal scales of variability. Estuaries 8(4): 342-351

Rondell JB, Finster KW, Lomstein BA (2000) Urea and DON uptake by a Lyngbya gracialis dominated microbial mat: a controlled laboratory experiment. Aquat Microb Ecol 21: 169-175

Rowe GT, Clifford CH, Smith KL Jr, Hamilton PL (1975) Benthic nutrient regeneration and its coupling to primary productivity in coastal waters. Nature 255:215-217

Rudek J, Paerl HW, Mallin MA, Bates PA (1991) Seasonal and hydrological control of phytoplankton nutrient limitation in the lower Neuse River estuary, North Carolina. Mar Ecol Prog Ser 75:133-142

Rueter JE, Loeb SL, Goldman CR (1986) Inorganic nitrogen uptake by epilithic periphyton in a $\mathrm{N}$-deficient lake. Limnol Oceanogr 31(1):149-160

Rysgaard S, Risgaard-Petersen N, Sloth NP (1996) Nitrification, denitrification, and nitrate ammonification in sediments of two coastal lagoons in southern France. Hydrobiologia 329:133-141

Rysgaard S, Christensen PB, Sørensen MV, Funch P, Berg P (2000) Marine meiofauna, carbon and nitrogen mineralisation in sandy and soft sediments of Disko Bay, West Greenland. Aquat Microb Ecol 21:59-71

Seitzinger SP (1987) Nitrogen biogeochemistry in an unpolluted estuary: the importance of benthic denitrification. Mar Ecol Prog Ser 41:177-186

Smith CJ, Delaune RD, Patrick WH (1982) Nitrate reduction in Spartina alternifolia marsh soil. Soil Sci Soc Am J 46: $748-750$

Sundback K (1986) What are the benthic microalgae doing on the bottom of Laholm Bay? Ophelia 4:273-286

Sundback K, Graneli W (1988) Influence of microphytobenthos on the nutrient flux between sediment and water: laboratory study. Mar Ecol Prog Ser 43:63-69

Sundback K, Miles A (2000) Balance between denitrification and microalgal incorporation of nitrogen in microtidal sediments, NE Kattegat. Aquat Microb Ecol 22:291-300

Tenore KR (1988) Nitrogen in benthic food chains. In: Blackburn $\mathrm{TH}$, Sørensen J (eds) Nitrogen cycling in coastal marine environments. John Wiley \& Sons, Chichester, p 191-206

Twilley RR, McKee B (1996) Ecosystem analysis of the Louisiana Bight and adjacent shelf environments, Vol I. The fate of organic matter and nutrients in the sediments of the Louisiana Bight. US Department of the Interior, New Orleans, LA

Twilley RR, Cowan J, Miller-Way T, Montagna PA, Mortazavi $B$ (1999) Benthic nutrient fluxes in selected estuaries in the Gulf of Mexico. In: Bianchi TS, Pennock JR, Twilley RR (eds) Biogeochemistry of Gulf of Mexico estuaries. John Wiley \& Sons, New York, p 163-209

Valderamma JC (1981) The simultaneous analysis of TP and TN in natural waters. Mar Chem 10:109-122

Valiela I (1995) Marine ecological processes. Springer-Verlag, New York

van Duyl FC, Kop AJ (1994) Bacterial production in North Sea sediments: clues to seasonal and spatial variations. Mar Biol 120:323-337

van Duyl FC, van Raaphorst W, Kop AJ (1993) Benthic bacterial production and nutrient sediment-water exchange in sandy North Sea sediments. Mar Ecol Prog Ser 100:85-95

Zimmerman AR, Benner R (1994) Denitrification, nutrient regeneration and carbon mineralization in sediments of Galveston Bay, Texas, USA. Mar Ecol Prog Ser 114: 275-288 